\title{
Post-glacial landform evolution in the middle Satluj River valley, India: Implications towards understanding the climate tectonic interactions
}

\author{
Shubhra Sharma ${ }^{1,2, *}$, S K BARtarya ${ }^{1}$ and B S MARH ${ }^{2}$ \\ ${ }^{1}$ Wadia Institute of Himalayan Geology, Dehradun, India. \\ ${ }^{2}$ Department of Geography, Himachal Pradesh University, Shimla, India. \\ ${ }^{*}$ Corresponding author. e-mail: shubshubhra@gmail.com
}

Late Quaternary landform evolution in monsoon-dominated middle Satluj valley is reconstructed using the fragmentary records of fluvial terraces, alluvial fans, debris flows, paleo-flood deposits, and epigenetic gorges. Based on detailed field mapping, alluvial stratigraphy, sedimentology and optical chronology, two phases of fluvial aggradations are identified. The older aggradation event dated between $\sim 13$ and 11 ka (early-Holocene), occurred in the pre-existing topography carved by multiple events of erosion and incision. Climatically, the event corresponds to the post-glacial strengthened Indian summer monsoon (ISM). The younger aggradation event dated between $\sim 5$ and 0.4 ka (mid- to late-Holocene), was during the declining phase of ISM. The terrain witnessed high magnitude floods during transitional climate $(\sim 6.5-7 \mathrm{ka})$. The fluvial sedimentation was punctuated by short-lived debris flows and alluvial fans during the LGM (weak ISM), early to mid-Holocene transition climate and mid- to late-Holocene declining ISM. Based on the terrace morphology, an event of relatively enhanced surface uplift is inferred after late Holocene. The present study suggests that post-glacial landforms in the middle Satluj valley owe their genesis to the interplay between the climate variability and local/regional tectonic interactions.

\section{Introduction}

The Indian summer monsoon (ISM) is considered to have profound control on earth surface processes and landscape development in monsoon-dominated Southern Mountain Front (SMF), located to the south of Main Central Thrust (MCT) in the Himalaya. The terrain experiences accelerated erosion due to a combination of focussed high intensity rainfall and seismicity (Hancock and Anderson 2002; Thiede et al. 2004; Bookhagen et al. 2005; Wobus et al. 2005; Clift et al. 2012). Himalayan fluvial systems show a strong relationship between ISM and fluvial dynamics as $\sim 80 \%$ of the annual flow is discharged during ISM along with most of the sediment production and transportation (Goodbred 2003; Wulf et al. 2012). The monsoon intensity controls erosive potential and carrying capacity of the fluvial systems by influencing the discharge and hence, the stream power.

Though not unanimously, it is suggested that fluvial aggradation occurs during wetter climate due to enhanced sediment flux whereas, incision is facilitated during reduced sediment supply in drier climate (Bogaart and Balen 2000; Pratt et al. 2002; Juyal et al. 2010; Chaudhary et al. 2015). Increased monsoonal precipitation also heightens the pore pressure causing slope failures and activates processes like landslides, debris flows, and/ or alluvial fans (Schmidt and Montgomery 1995;

Keywords. Paleo-climate; late Quaternary; Indian summer monsoon; fluvial terraces; alluvial fan; debris flow; optical chronology. 
Vandenberghe 1995; Pratt et al. 2002; Attal and Lave 2006) along with the mobilization of glaciogenic sediments eventually causing valley floor aggradation (Blöthe and Korup 2013). Whereas, incision begins once the sediment flux decreases and stream power increases due to continued bedrock uplift in the Himalaya (Pratt-Sitaula et al. 2004; Bookhagen et al. 2006). Contrary to this, evidence from upper Ganga valley suggests that phases of valley-fills were associated with periods of weak monsoons such as the Last Glacial Maximum (LGM) and the Younger Dryas (YD) whereas, incision occurred during the strengthened monsoon (Srivastava et al. 2008; Ray and Srivastava 2010). Glaciers, being potent erosive agents, control sediment supply in the Himalaya. A recent study demonstrates that compared to western and eastern Himalaya, aggressive fluvial erosion in central Himalaya, limits the amount of glaciogenic sediments sequestered in relict glaciated valleys (Blöthe and Korup 2013). Implying that in the central Himalaya, appreciable mobilization and hence contribution towards the valley-fill aggradation would have occurred during periods of deglaciation (Benn and Owen 1998; Juyal et al. 2010). Extreme events like debris flows, landslides, and floods in the Himalaya are known to limit the relief (Barnard et al. 2001; Korup et al. 2010). Being potent erosive agents, in a non-glaciated terrain like middle Satluj valley extreme events shape the landscape besides augmenting sediment supply into river valleys (Pearce and Watson 1983; Griffiths and Webb 2004; Lancaster and Grant McKoy 2006; Anderson et al. 2015). The sediment supply is often in surges and is enhanced especially during catastrophic flash floods which causes incision and erosion of the landforms besides modifying the channel morphology (Eaton and Lapointe 2001; Baker 2002; Waitt 2002; Kale 2003, 2007).

Evidences from the Indian subcontinent suggest considerable variability in ISM during the last $20 \mathrm{ka}$ (Juyal et al. 2004, 2009; Sharma et al. 2004; Sinha et al. 2005). Fluvial landforms in the Himalaya have been widely investigated to understand relationship between monsoon variability and fluvial dynamics (Pratt et al. 2002; Pratt-Sitaula et al. 2004; Bookhagen et al. 2006; Srivastava et al. 2008; Juyal et al. 2010; Ray and Srivastava 2010). There are some studies on the genesis and climatic significance of debris flows, alluvial fans, landslides, epigenetic gorges, and paleo-flood deposits (Scheidegger 1998; Viseras et al. 2003; Barnard et al. 2004; Malamuda et al. 2004; Bookhagen et al. 2005; Suresh et al. 2007; Ouimet et al. 2008; Wasson et al. 2008, 2013; Zygmunt 2009; 2012; Kothyari and Juyal 2013). However, integrating the variegated landforms and providing an understanding of the response of earth surface processes to spatial and temporal changes in climate and tectonics are scanty.

The present study is therefore, an attempt to (i) understand the causes of spatial and temporal variability in the late Quaternary landforms, (ii) to generate a preliminary model of landform evolution in the middle Satluj valley and (iii) to ascertain the role of climate and tectonics in evolution of landforms.

\section{Study area}

Satluj river is the largest tributary of Indus River and drains third largest catchment area in Himalaya with $>80 \%$ of the river catchment located in rain shadow zone with scanty vegetation $(>4000 \mathrm{~m})$. In the lower reaches $(<4000 \mathrm{~m})$, particularly in the $\mathrm{SMF}$, ISM is the major contributor to river discharge with peak flow during monsoons. The rainfall is concentrated near two orographic barriers, viz., the Main Boundary Thrust (MBT) and the Main Central Thrust (MCT) (Bookhagen et al. 2006).

The present study area lies in the lesser Himalayan domain of the middle Satluj valley $\left(31^{\circ} 14^{\prime}\right.$ $\left.57.08^{\prime \prime}-31^{\circ} 14^{\prime} 58.82^{\prime \prime} \mathrm{N} ; \quad 77^{\circ} 4^{\prime} 55.33^{\prime \prime}-77^{\circ} 7^{\prime} 21.87^{\prime \prime} \mathrm{E}\right)$ with elevation ranging between 600 and $900 \mathrm{~m}$ (figure 1). The valley morphology alternates between wide and narrow segments between the MCT (Rampur) and Shalighat Thrust (Tattapani). Mean rainfall varies between 813 and $1280 \mathrm{~mm}$ of which the maximum precipitation occurs during the summer monsoon. Rampur and Sunni areas are the zones of high precipitation (Luhri Project Report 2010).

The terrain is traversed by Suketi Thrust (Jutogh Thrust) near Behna and Shalighat thrust near Tattapani. The Suketi Thrust separates phyllites from limestone and dolomite whereas, the Shalighat thrust demarcates the limestone and dolomite from shale and silt-stone (GSI 1976; Srikantia and Bhargava 1988; Thakur and Rawat 1992) (figure 1).

\section{Methodology}

Landform mapping is carried out using the satellite imageries followed by detailed field investigation. The imageries with datum WGS84 were geo-referenced and digitized using ArcGIS 10.2 software. In a bedrock river, valley morphology plays an important role in aggradation and incision (Grant and Swanson 1995). The spatial changes in valley morphology is ascertained using valley width (W) to depth ratio (D) which is expressed as $\alpha=\mathrm{WD}$ (Finnegan et al. 2005). Tributary cross-section profiles and slope of the catchments were calculated by using ASTER GDEM-level 1B 


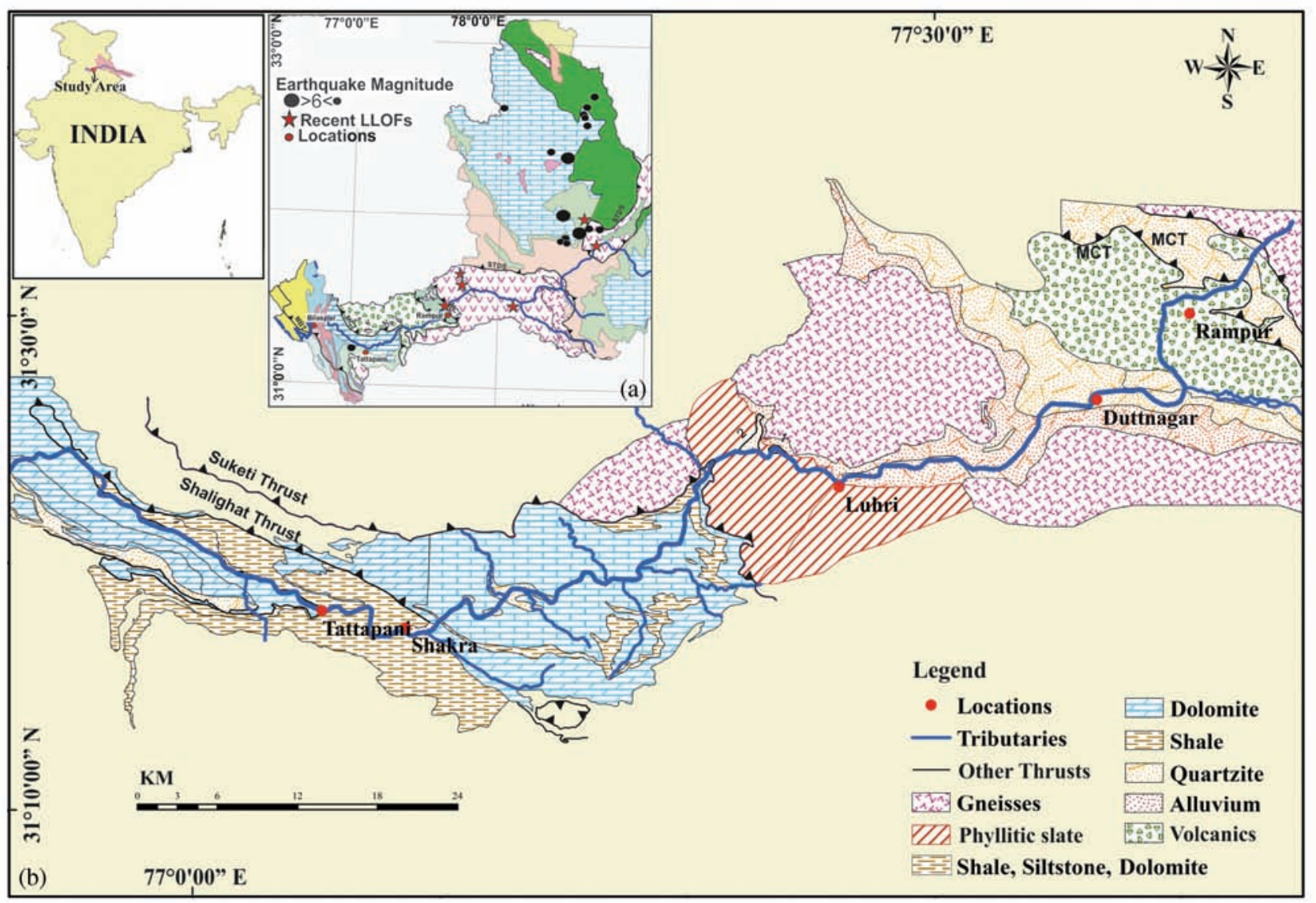

Figure 1. Regional geological map of the middle Satluj valley (modified after GSI memoirs 1976 and Thakur and Rawat 1992). (a) Inset showing major earthquakes in the valley (modified after Wulf et al. 2012) and (b) recent events of Landslide Lake Outburst (LLOFs) (source: DDMA, Kinnaur; Gupta and Shah 2008; Wulf et al. 2012).

(Advanced Space borne Thermal Emission and Reflection Radiometer Global Digital Elevation Model (spatial resolution $30 \mathrm{~m}$ ) in ArcGIS 10.2 software.

The spatial and lateral variability of the sedimentary sequences is documented in the field using conventional sedimentological techniques. In order to ascertain the sediment provenance, lithoclast analyses using $1 \times 1 \mathrm{~m}$ grid overlays is employed on the exposed fluvial terraces.

Chronology of the sediment is obtained using Optically Stimulated Luminescence (OSL) dating technique. OSL provides the deposition age of the sediment and relies upon the premise that geological luminescence is reset to zero by daylight exposure during sediment transportation (Aitken 1998). The ages are obtained using the modified single aliquot regeneration (SAR) protocol of Murray and Wintle (2000), where contribution from feldspar is reduced by IR simulation before measuring OSL signal from quartz (Banerjee et al. 1999; Roberts and Wintle 2001; Zhang and Zhou 2007). Quartz is extracted through sequential pre-treatment using $10 \% \mathrm{HCl}$ and $30 \% \mathrm{H}_{2} \mathrm{O}_{2}$ to remove the carbonates and organic carbon respectively and sieved to obtain 90-125 $\mu \mathrm{m}$ size fraction. Quartz and feldspar minerals were separated using Na-polytungstate $\left(\rho=2.58 \mathrm{~g} / \mathrm{cm}^{3}\right)$ and magnetic separation, which are etched for $80 \mathrm{~min}$ in $40 \% \mathrm{HF}$ followed by $10 \mathrm{~N} \mathrm{HCl}$ for $30 \mathrm{~min}$ to remove the outer alpha irradiated skin. The equivalent doses $\left(D_{e}\right)$ were measured using modified single aliquot regeneration (double SAR) (Murray and Wintle 2000; Banerjee et al. 1999) protocol with preheat of $240^{\circ} \mathrm{C}$ for 10 sec and cut heat of $200^{\circ} \mathrm{C}$. The OSL were measured at $125^{\circ} \mathrm{C}$ for $40 \mathrm{sec}$ and prior to every OSL measurement, infrared stimulated luminescence (IRSL) were measured at $50^{\circ} \mathrm{C}$ for $100 \mathrm{sec}$ to remove any contribution from feldspar.

\section{Results}

Based on morphology and sediment assemblages, five major landforms are identified. These are:

(i) the fluvial terraces (valley-fill and strath),

(ii) paleo-flood deposits, 
(iii) debris flows/landslide deposits,

(iv) alluvial fans, and

(v) relict valleys and epigenetic gorges (figure $2 \mathrm{a}$ and $b)$.

Detailed description of each landform is given below.

\subsection{Fluvial terraces}

Fluvial terraces and landforms have been used to reconstruct the history of Quaternary climate oscillations and tectonic uplift (Starkel 2003; Bridgland and Westaway 2008; Vandenberghe 1995). In actively uplifting orogen like Himalaya, rivers are dominantly involved in incising the underlying resistant bedrock (Whipple 2004). As a result, the fluvial sequences are discontinuous and patchy (Howard et al. 1994).
In the middle Satluj valley, two phases of aggradations in the form of asymmetrically paired terraces are identified in the wider valley segments (figure 3). The flat topped topography of the fluvially aggraded surfaces is differentiated with distinct vertical offsets of $\sim 80 \mathrm{~m}$ between older aggradation surface (terrace T2) and younger aggradation surface (terrace $\mathrm{T} 1$ ) and $5-10 \mathrm{~m}$ between younger aggradation surface and present day river channel. The terrace sediments overlie bevelled bedrock strath surfaces of variable thickness (figures $2 \mathrm{~b}$ and 3 ). Following the definition of Bull (1991), the bevelled bedrock with alluvial thickness $<10 \mathrm{~m}$ are termed as strath terraces whereas, surfaces with alluvial thickness $>10 \mathrm{~m}$ are termed as fill terrace. Thus, older aggradation surface (T2) is classified as valley-fill terrace, whereas, the younger aggradation surface (T1) is identified as strath terrace.

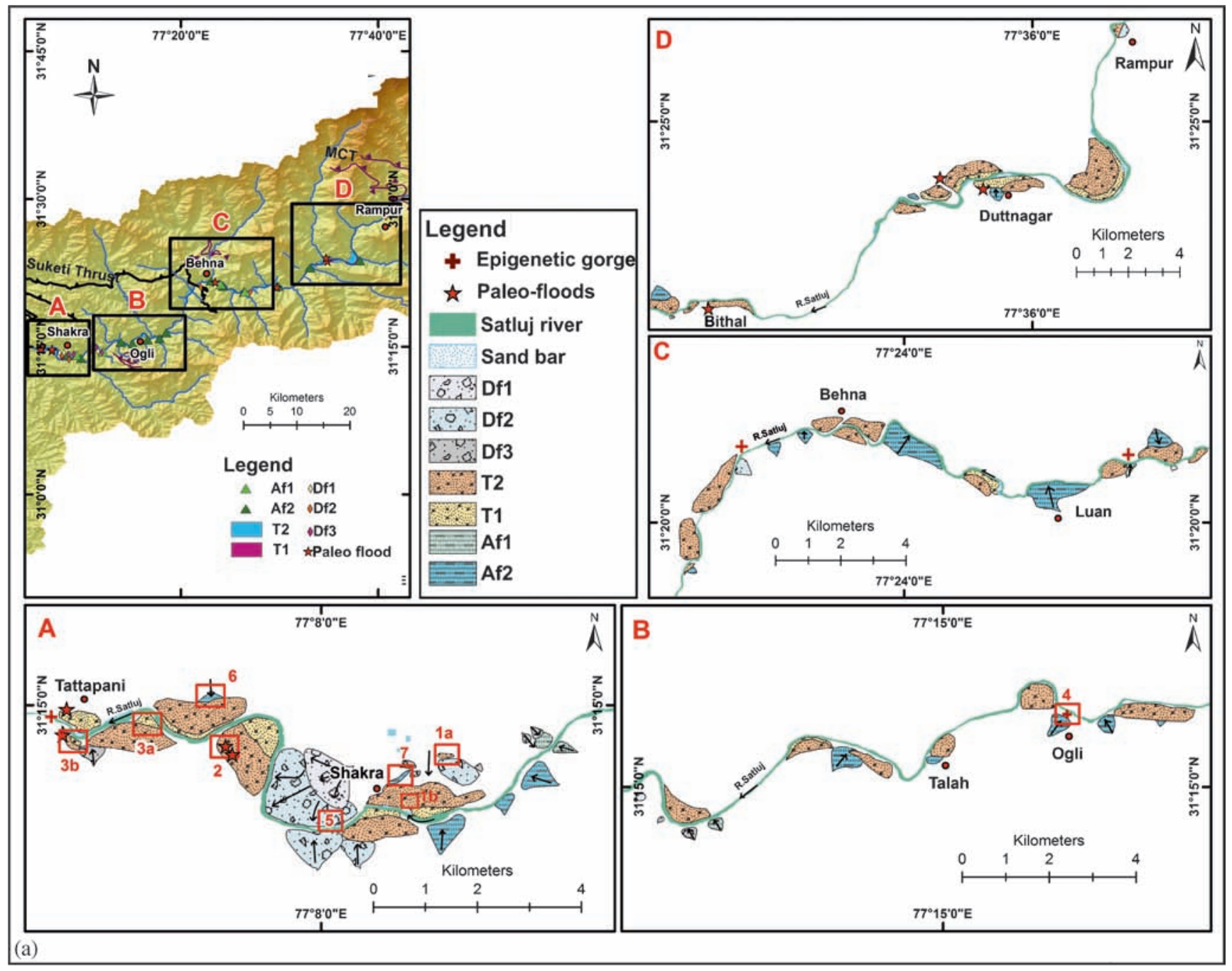

Figure 2(a). Inset at the top marks the geomorphic maps (A-D) of the study area between Tattapani and Rampur showing various landforms. In maps (A-D), T2 and T1 are aggradation surfaces, DF3, DF2, and DF1 are debris flows and AF2 and AF1 are alluvial fans. The insets marked as (1-7) give the location of field photographs of various landforms (as shown in figure $2 \mathrm{~b}$ on the next page). 

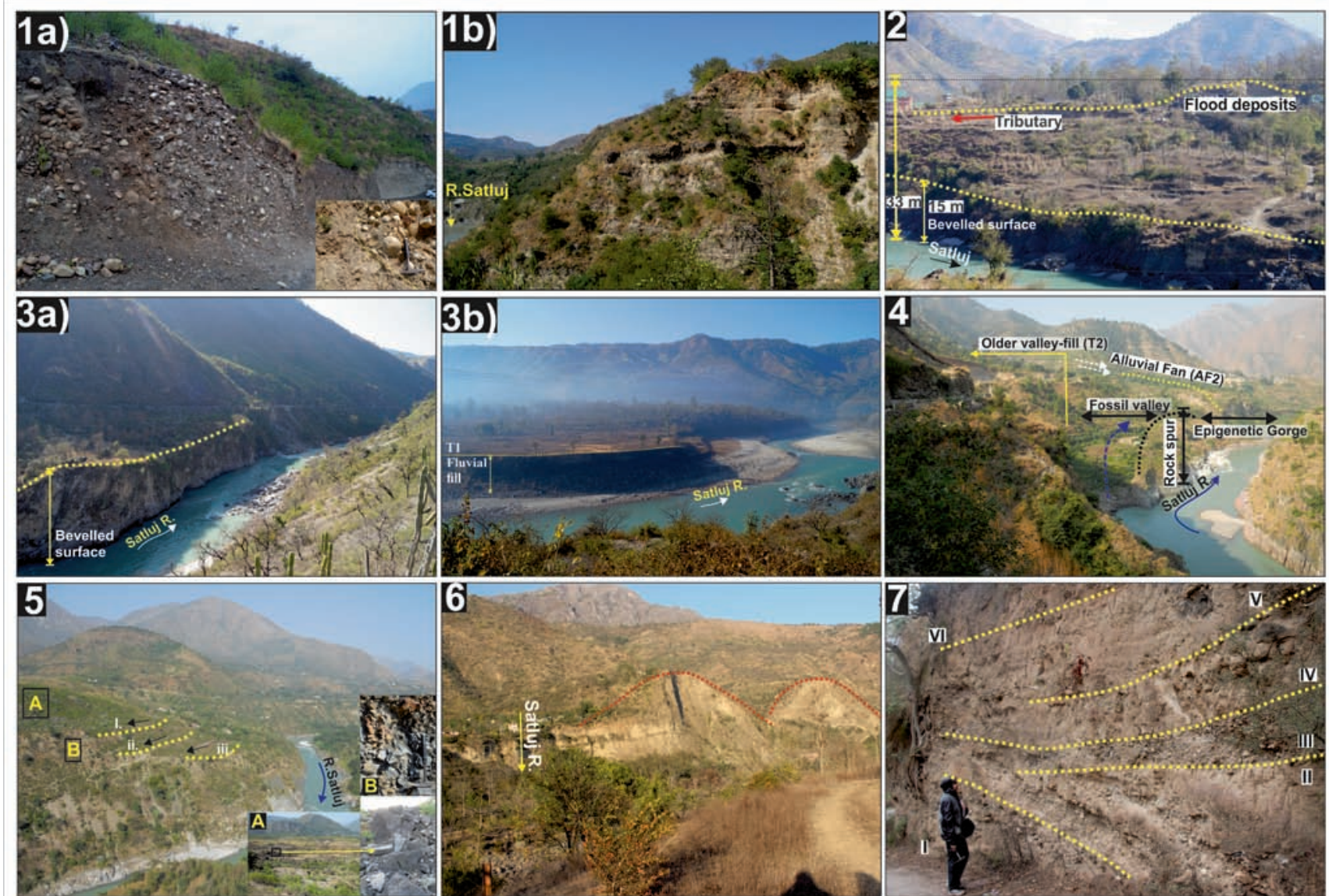

(b)

Figure 2(b). Field photographs in (1a and 1b) represent older aggradation surface (T2) at Shakra with inset in (1a) showing the contact with debris flow deposits. (2) Paleo-flood deposits at Sunni overlying the younger aggradation surface (T1). Seasonal tributary stream (marked with red arrow). (3) (a and b) Bevelled bedrock at Shakra and at Tattapani respectively. (4) Epigenetic gorge at Ogli associated with younger aggradation surface (T1). (5) Undulating surface of Ghanghar composed of multiple debris flows (marked as (B)), with landslide deposits on the surface (marked as (A)). The distal end of the Ghanghar is modified into three levels of terraces (marked i, ii and iii). (6) Red dotted line marks the alluvial fan incised by Satluj River which appear as triangular facets opposite Sunni. (7) Fining upward sedimentary units of alluvial fan at Shakra.

\subsubsection{Older aggradation phase (T2)}

In the wider segment of the river valley, older aggradation phase with distinct tabletop topography lies at elevation ranging from 10 to $90 \mathrm{~m}$ above the present river channel. Terrace gravels are weakto-moderately lithified, and at places contain landslides and debris flow/alluvial fan deposits, particularly near MCT zone (below Rampur and Sainj). Although the surface is preserved at multiple locations, below the sediment successions preserved at Shakra and Rampur are discussed (figure 4).

Shakra $\left(31^{\circ} 13^{\prime} 56.8^{\prime \prime} \mathrm{N} ; 77^{\circ} 09^{\prime} 21.6^{\prime \prime} \mathrm{E}\right)$ : Older aggradation surface is preserved at an elevation of $\sim 90$ $\mathrm{m}$ from the present day river bed and can be traced laterally for $\sim 2 \mathrm{~km}$ upstream. A NE-SW draining seasonal stream has incised $\sim 34 \mathrm{~m}$ thick sediment succession on the right bank of Satluj River. Based on broad textural variability, six sedimentary units have been identified.
Stratigraphy: From bottom upwards (base unexposed), 10-m thick, matrix-supported, rounded and imbricated gravel grades into subrounded gravel along with decrease in clast size and increase in matrix proportion towards the upper part (unitI). This is overlain by $\sim 5 \mathrm{~m}$ thick, clast supported and moderately imbricated rounded to subrounded gravel (unit-II), which is succeeded by $\sim 4 \mathrm{~m}$ thick, matrix supported, rounded to subrounded gravel, interspersed with sand lenses (unit-III). This is followed by $\sim 4 \mathrm{~m}$ thick matrix supported, rounded to subrounded gravel containing impersistent sand lenses (unit-IV). Unit-V is $\sim 4 \mathrm{~m}$ thick, subrounded, poorly organised, matrix supported gravel, capped by $\sim 2 \mathrm{~m}$ thick moderately weathered coarse to medium sand containing discrete slope wash and gravel deposit (unit-VI). Lithoclast analysis of randomly selected 300 gravel samples indicates dominance of quartzite $(57 \%)$, followed by granite $(25 \%)$, slate and phyllite $(17 \%)$. 


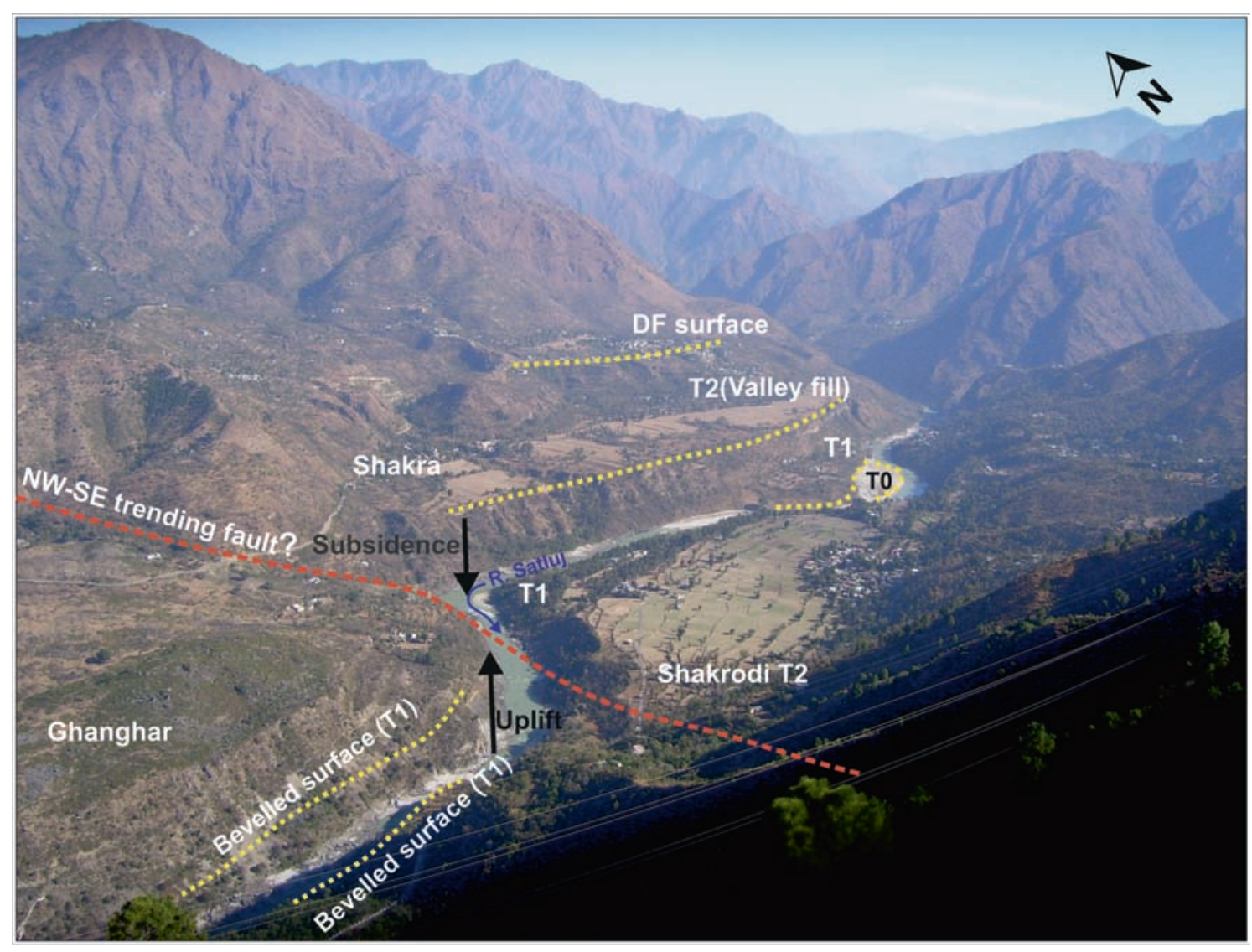

Figure 3. Panoramic view of the Satluj valley around Shakra with two aggradation surfaces (valley-fills T2 and T1). A prominent bevelled strath surface overlain by debris flow towards the downstream segment is inferred as an expression of the differential movement along the inferred NW-SE trending fault (shown in red dotted line) and sense of movement is marked by the black arrows.

Depositional environment: The sedimentary architecture of older aggradation surface suggests change in sediment-water ratio caused due to fluctuating hydrological discharge during the deposition of various units. For example, the flow regime changed from steady water flows with reduced sediment-water ratio to low flow velocities and low water depths with decreased stream competency, as indicated by the imbricated and moderately sorted gravel changing to matrix dominated, crudely fining-upward lithoclast, with random orientation (Miall 1996; Reading 2009). Evidence of the increase in flow velocity with variable hydrological discharge can be inferred based on the presence of moderately imbricated clast-supported gravels of variant clast size (Smith 1986; Miall 1996; Reading 2009). The impersistent sand lenses (point bars) indicate change in the hydrological condition with short-lived high magnitude discharge followed by a prolonged low flow regime (Miall 1996; Reading 2009; Dutta et al. 2012); whereas, the matrix-supported gravel suggests irregular and flashy discharge with dominance of hyper-concentrated flood events (Smith 1986; Juyal et al. 2010). Persistent angular boulder layer indicate activation of slope activity for a short time during the aggradation event. Lithoclasts show dominance of quartzite, granite and gneisses implying sediment contribution from the Higher Himalayan catchment.

Duttnagar $\left(31^{\circ} 23^{\prime} 41.8^{\prime \prime} \mathrm{N} ; 77^{\circ} 35^{\prime} 03.3^{\prime \prime} \mathrm{E}\right)$ : This section is exposed along the road upstream near Rampur and lies $\sim 50 \mathrm{~m}$ above the river bed.

Stratigraphy: A total of six units can be distinguished. At the bottom is $\sim 2.15 \mathrm{~m}$ thick, assorted, matrix supported, rounded to subrounded gravel (unit-I) followed by $\sim 0.5 \mathrm{~m}$ thick, coarse to medium sand lens (unit-II). Unit-III is $\sim 1.5 \mathrm{~m}$ thick, matrix supported, largely assorted, rounded to subrounded gravel and is succeeded by $\sim 0.3 \mathrm{~m}$ thick, medium to fine sand layer (unit-IV). Unit-V is $\sim 2.15 \mathrm{~m}$ thick, moderately sorted, matrix supported, rounded to subrounded gravel followed by $\sim 4$ m thick, coarse sand layer (unit-VI).

Depositional environment: The textural characteristics indicate fluctuating hydrological conditions which varied between high flow regime (irregular appearance of rounded to subrounded gravels) to low flow regime (point bars) (Singh et al. 2007). Presence of uppermost sand lens indicates 


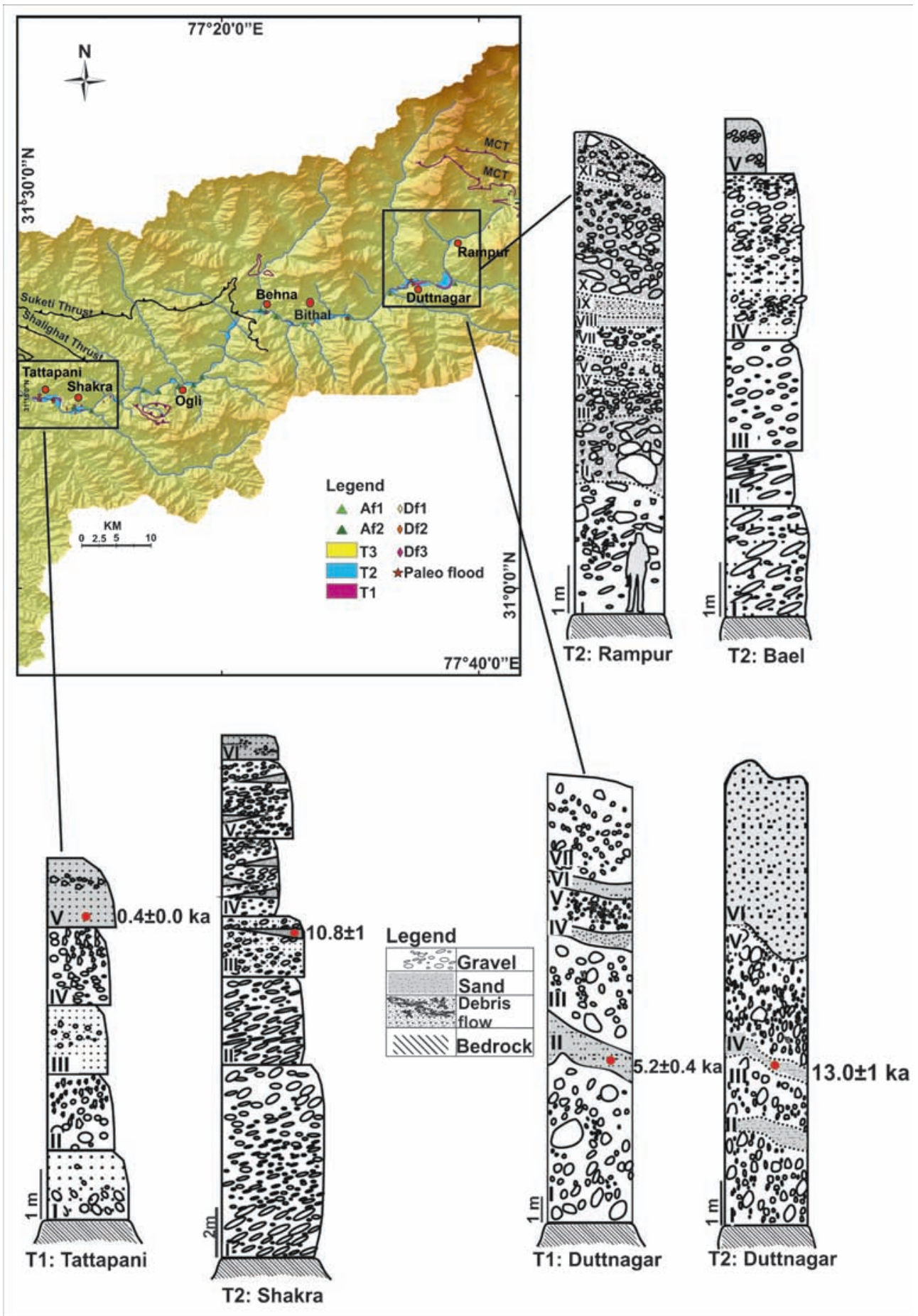

Figure 4. Stratigraphy of older aggradation surface (T2) and younger aggradation surface (T1) at different locations in the study area. Optical ages indicate that older aggradation surface (T2) formed during 13 to 11 ka after the Last Glacial Maximum. Note the temporal changes in the facies architecture in Rampur terrace (fluvial, debris flow alteration) signify terrain instability during strengthened ISM in the vicinity of the Main Central Thrust (MCT). The youngest aggradation surface (T1) dated to $\sim 5 \mathrm{ka}$ and 0.4 ka suggest deposition under declining ISM.

decline in the hydrological conditions leading to the river experienced lateral channel avulsion (Singh et al. 2007).

Bael $\left(31^{\circ} 24^{\prime} 2.772^{\prime \prime} \mathrm{N} ; 77^{\circ} 35^{\prime} 41.0274^{\prime \prime} \mathrm{E}\right)$ : On the opposite flank, asymmetrical pair of older aggradation surface of Duttnagar is present $\sim 50 \mathrm{~m}$ above the river bed. The fluvial succession is terminated by an alluvial fan.

Stratigraphy: Based on the textural variability, five stratigraphic units can be discerned. The lowermost unit-I is $\sim 2 \mathrm{~m}$ thick, matrix supported, assorted, subrounded to subangular gravel and 
is overlain by $\sim 1 \mathrm{~m}$ thick, subrounded boulders (unit-II). Unit-III is $\sim 2 \mathrm{~m}$ thick, clast supported, subrounded to rounded gravels, followed by $\sim 3 \mathrm{~m}$ thick, assorted matrix dominated subrounded to rounded gravels (unit-IV). Succeeding unit-V is $\sim 1 \mathrm{~m}$ thick, medium to coarse sand layer, interspersed with subrounded gravel. The succession is terminated with the deposition of $\sim 4 \mathrm{~m}$ thick, alluvial fan sequence.

Depositional environment: The temporal changes in the textural attributes suggest that the fluvial discharge fluctuates between cohesive debris flows (matrix supported, assorted, subrounded to subangular gravel) to non-cohesive persistent stream flow (clast supported subrounded to rounded gravel). Towards the upper part, deposition of sand layer indicates decline in the hydrological conditions (Reading 2009).

Rampur $\left(31^{\circ} 26^{\prime} 35.52^{\prime \prime} \mathrm{N} ; 77^{\circ} 37^{\prime} 44.3274^{\prime \prime} \mathrm{E}\right)$ : Around Rampur, older surface is exposed along the road on the left bank of Satluj River at an elevation of $\sim 65 \mathrm{~m}$ above the present river bed. The $\sim 20 \mathrm{~m}$ thick sediment succession comprises of alternating fluvial gravel mixed with debris flow/landslide deposits.

Stratigraphy: The sequence begin with deposition of $\sim 3 \mathrm{~m}$ thick clast-supported, imbricated, subrounded fluvial gravel with discrete angular boulders (unit-I). This is followed by $\sim 2 \mathrm{~m}$ thick, randomly oriented, angular boulders embedded in gritty matrix containing crudely fining upwards, lensoidal pebbly gritty sand (alluvial fan facies) (unit-II). Overlying this is $\sim 1 \mathrm{~m}$ thick, rounded to subrounded, moderately sorted, matrix supported gravel (unit-III). This is followed by $0.5 \mathrm{~m}$ thick, angular lithoclast embedded in gritty matrix (unitIV) and is succeeded by $\sim 1 \mathrm{~m}$ thick, swelling and pinching, moderately sorted, matrix-supported rounded to subrounded gravel (unit-V). This is followed by $\sim 0.3 \mathrm{~m}$ thick, angular boulders embedded in platy lithoclast dominated matrix (unit-VI). This unit is succeeded by $\sim 1 \mathrm{~m}$ thick, rounded to subrounded, moderately sorted and imbricated, clast-supported gravel (unit-VII). Overlying this is $\sim 0.5 \mathrm{~m}$ thick, swelling and pinching, crudely laminated, coarse to medium sand (unit-VIII). A distinct platy lithoclast dominated layer (debris flow facies) of $\sim 0.5 \mathrm{~m}$ overlies this unit (unit-IX) which is succeeded by a massive $\sim 4 \mathrm{~m}$ thick, crudely finning upwards, matrix supported, angular to subrounded, crudely imbricated gravel (unit-X). Finally, $\sim 2 \mathrm{~m}$ thick, assorted, angular lithoclast embedded in gritty and sandy matrix (unit-XI) marks the termination of sedimentation at this location.

Depositional environment: The textural variability and sedimentary architecture indicate mobilization of sediments both from the upper catchment and the surrounding valley slopes. It has been observed that such sedimentary packages are associated with overall strengthened ISM, during which mobilization of sediment occurs from nearby hill slopes due to increased pore water pressure (Miall 1996; Pratt et al. 2002).

\subsubsection{Younger aggradation phase (T1)}

Younger aggradation phase is widespread in the middle Satluj valley. Detailed sedimentological observations are made at Tattapani and Duttnagar (figure 4), where the aggradation surfaces appear as wide flat-toped surfaces covered with varying sediment thickness $(0-8 \mathrm{~m})$. At places, the younger surface is represented by incised bevelled bedrock up to a depth of $\sim 2-5 \mathrm{~m}$ (e.g., between Tattapani and Sunni) and is covered with recent to subrecent flood sediments (figures $2 \mathrm{~b}$ and 4 ).

Tattapani $\left(31^{\circ} 14^{\prime} 41.8^{\prime \prime} \mathrm{N} ; 77^{\circ} 05^{\prime} 41.2^{\prime \prime} \mathrm{E}\right)$ : Around Tattapani, the surface is represented by $\sim 7 \mathrm{~m}$ thick sediment fill overlying the bevelled bedrock, which occur $\sim 8 \mathrm{~m}$ above the present day river bed. The sediments are unconsolidated, matrix supported, relatively fresh, poorly imbricated and contain admixture of locally driven slope wash (figure 4).

Stratigraphy: A total of five stratigraphic units overlying phyllite bedrock strath can be discerned. From bottom upwards is $\sim 1.25 \mathrm{~m}$ thick, matrix supported, rounded, imbricated gravel (unit-I), followed by $\sim 1.50 \mathrm{~m}$ thick, poorly sorted, angular to rounded boulders embedded in gritty sand (unitII). It is overlain by $\sim 1.25 \mathrm{~m}$ thick, coarse sand with occasional boulders (unit-III). Overlying it is $\sim 1.5 \mathrm{~m}$ thick, poorly sorted, angular to subrounded gravel (unit-IV) capped by $1.5 \mathrm{~m}$ thick, coarse to medium sand punctuated with locally derived platy phyllite lithoclast (unit-V). Lithoclast analyses show dominance of slate (30\%), followed by quartzite $(29 \%)$, dolomite $(23 \%)$, crystalline $(16 \%)$ and granite $(2 \%)$.

Depositional environment: Bevelled bedrock strath underlying the fill sediment suggests lateral erosion dominated over vertical incision implying a phase of relative tectonic stability. Conceptually, strath formation requires changes in the ratio of vertical incision to lateral planation (Hancock and Anderson 2002). Further, due to the limited sediment supply from upper catchment and adjoining valley slopes, fluvial energy was utilized for the bedrock incision (Pratt et al. 2002). The hydrological conditions were fluctuating as the river environment changed from point bar to mid-channel bar as indicated by the deposition of alternating sand and sandy gravel (Singh et al. 2007).

Duttnagar $\left(31^{\circ} 23^{\prime} 41.8^{\prime \prime} \mathrm{N} ; 77^{\circ} 35^{\prime} 03.3^{\prime \prime} \mathrm{E}\right)$ : The $\sim 8 \mathrm{~m}$ thick sediment succession is preserved above 
the present river bed and overlies the bevelled bedrock.

Stratigraphy: The lowermost unit-I is $\sim 1.5 \mathrm{~m}$ thick, matrix supported, moderately sorted gravel, followed by $\sim 0.5 \mathrm{~m}$ thick, coarse to fine sand with granules (unit-II). Unit-III is $\sim 1.5 \mathrm{~m}$ thick, matrix supported, moderately sorted, gravel and is overlain by $\sim 0.5 \mathrm{~m}$ thick, coarse sand lens (unit-IV). This is succeeded by $\sim 0.5 \mathrm{~m}$ thick, matrix supported, rounded to subrounded gravel (unit-V). This is followed by $\sim 0.5 \mathrm{~m}$ thick, gritty-coarse sand lens (unit-VI). The uppermost unit-VII is $\sim 1.5 \mathrm{~m}$ thick, matrix supported, moderately sorted, subrounded to rounded gravel.

Depositional environment: The facies architecture indicates fluctuating hydrological discharge with alternating mid-channel and point bar deposits. The water depth and sediment to water ratio was fluctuating as indicated by the variability in lithoclast size and intervening matrix (Miall 1996; Singh et al. 2007).

\subsection{Debris flows (DF)}

Debris flows are gravity-driven, highly concentrated mixtures of sediment and water, commonly composed of poorly sorted lithoclast, matrix supported sediment ranging in size from clay to cobbles and boulders (Jahns 1949; Fisher 1971; Pierson 1980; Major 1997; Lavigne and Suwa 2004; Leeder 2009). The texture of the lithoclast is governed by sediment provenance, distance of transportation and amount of water involved during transportation (Major 1997). In mountain areas, the deposits are usually associated with rainfall induced runoff causing failure of debris-laden slopes/landslides (Iverson et al. 1997). In order to generate debris flow, there should be enough weathered bedrock or colluvium wedges in catchment (Iverson et al. 1997; Griffiths and Webb 2004). These are usually associated with smaller catchments which receive proportionally greater amount of water during rainstorms and have steeper slopes (Costa and Fleisher 1984).

In the study area, debris flows are associated with first or second order tributary streams having catchment area $<3 \mathrm{~km}^{2}$ and an average slope of 0.82. The profiles of debris flow catchments show a drastic drop in gradient as it opens into the trunk stream. The lithoclasts are dominated by local lithology, comprising of dolomite and slate with subordinate quartzite. On the basis of degree of lithification/cementation and various textural properties, three major generations of debris flows are identified, and are named as DF3 (oldest) to DF1 (youngest).

\subsubsection{Debris flow DF3}

Oldest debris flow deposits are lithified, subangular to angular, crudely sorted, clast supported, with corroded edges, coated with precipitated carbonate and give a metallic sound on striking with a hammer. These are preserved around Shakra $\left(31^{\circ} 14^{\prime} 22.60^{\prime \prime} \mathrm{N}, 77^{\circ} 8^{\prime} 54.70^{\prime \prime} \mathrm{E}\right.$; elevation $\left.846 \mathrm{~m}\right)$ and Tattapani $\left(31^{\circ} 14^{\prime} 30.1^{\prime \prime} \mathrm{N}, 77^{\circ} 05^{\prime} 28.0^{\prime \prime} \mathrm{E}\right.$; elevation $672 \mathrm{~m})$. DF3 shows a cross-cutting relationship with older aggradation surface.

\subsubsection{Debris flow DF2}

Dominated by non-lithified, poorly organized, matrix supported, angular to sub-angular lithoclast, the surface of the debris flow is gullied. The DF2 either overlie older aggradation surface or show a cross-cutting relationship with it.

\subsubsection{Debris flow DF1}

The youngest matrix supported debris flows are non-lithified and consists of platy angular lithoclasts of phyllite, slate and dolomite. The DF1 are inset within the older DF2 and incise through older aggradation surface.

Ghanghar: 'Ghanghar' in local parlance means irregular surface topography dominated by unorganized distribution of boulders. These occur between Shakra and Sunni (figure 2b) $\left(31^{\circ} 14^{\prime} 22.60^{\prime \prime} \mathrm{N}, 77^{\circ} 8^{\prime}\right.$ $54.70^{\prime \prime} \mathrm{E}$; elevation $846 \mathrm{~m}$ ), as triangular-shaped debris flow deposits corresponding to DF1 and DF2, which taper out radially in the distal part. Maximum thickness of the deposit $(\sim 50 \mathrm{~m})$ is observed in the central segment (figure $2 \mathrm{~b}$ ). According to a local folklore, large angular boulders on surface were transported during a historical landslide that emanated from the southern flank of Satluj River. Stratigraphically, 'Ghanghar' overlies older aggradation surface with its distal end bevelled into three terrace surfaces.

\subsection{Alluvial fans (AF)}

Alluvial fans are associated with second and higher order tributary streams having catchment area $>3 \mathrm{~km}^{2}$ and the average slope of 0.25 . Morphologically, the deposits appear as fans (cones) radiating downslope from tributary valleys due to the sediment mobilization during episodic rainfall events (Blair and McPherson 1994). The fan shape morphology develops due to frequent shifting of radial channels (braiding) from the nodal point of entry to depositional basin (Bull 1997; Leeder 2009). According to Blair (1999), alluvial fans facies occur as rhythmic, gravelly coarse to 
very coarse pebble layer and coarse gravelly sand couplets, with sharp bedding plain having occasional scouring at the base which is attributed to sediment laden flood events.

Deposits either show a cross-cutting relationship with older aggradation surface, or are truncated at the distal end, and thus, at places appear as vertical scars, for example, around Randhol ( $31^{\circ} 14^{\prime} 2.5^{\prime \prime}$ $\mathrm{N}, 77^{\circ} 06^{\prime} 33.3^{\prime \prime} \mathrm{E}$; elevation $660 \mathrm{~m}$ ) (figure $2 \mathrm{~b}$ ). At few places such as near Behna $\left(31^{\circ} 21^{\prime} 39.9^{\prime \prime} \mathrm{N}\right.$, $77^{\circ} 22^{\prime} 28.1^{\prime \prime} \mathrm{E}$; elevation $787 \mathrm{~m}$ ), these extend down to the river bed. Based on morpho-stratigraphic position, sedimentary architecture and degree of weathering/lithification, two generations of alluvial fan are identified.

\subsubsection{Older alluvial fan (AF2)}

The AF2 deposits are matrix supported, moderately lithified, and sorted. Texturally, a crudely fining upward succession can be observed in subangular platy gravel interspersed with swelling and pinching silty-sand layers. The sedimentological details at Shakra are discussed below.

Shakra $\left(31^{\circ} 14^{\prime} 13.3^{\prime \prime} \mathrm{N} ; 7^{\circ} 08^{\prime} 50.4^{\prime \prime} \mathrm{E}\right.$; elevation $739 \mathrm{~m}$ ): The alluvial fan is preserved on the right flank showing a cross-cutting relationship with older aggradation surface and can be traced in the upstream of a small tributary valley $\left(\sim 3 \mathrm{~km}^{2}\right)$ having a slope of 0.39 .

Stratigraphy: Sediments are moderately compact and facies architecture show crudely fining upward succession with imbricated sub-angular gravel layers (0.3-1 m thick) interspersed with pinching and swelling silty-sand layers ( $0.2-0.5 \mathrm{~m}$ thick). A total of six such units can be identified in a 6-m thick succession (figure 2b). The bottom-most horizon is $\sim 0.4 \mathrm{~m}$ thick, silty-sand with gritty granules (unit-I). It is overlain by $\sim 0.3 \mathrm{~m}$ thick, clast dominated, fining upwards, coarse, subrounded pebble layer (unit-II). Following this a $\sim 0.5 \mathrm{~m}$ thick, matrix dominated, sub-angular pebble and granule layer interspersed with silty-sand lenses (unitIII). It is overlain by $\sim 0.3 \mathrm{~m}$ thick, silty-sand lens with gritty granules (unit-IV). Unit- $\mathrm{V}$ is $\sim 0.2 \mathrm{~m}$ thick, matrix supported, angular to sub-angular pebble layer. Finally, $\sim 2 \mathrm{~m}$ thick, silty-sand lens with intervening angular pebble layers of $\sim 0.2 \mathrm{~m}$ thick, tops the fan sequence (unit-VI).

\subsubsection{Younger alluvial fan (AF1)}

The sediment associated with AF1 are non-lithified, poorly sorted, clast dominated, sub-angular lithoclasts with occasional boulders embedded in silty-sand matrix. Detailed stratigraphy of the alluvial fan exposed at Luan village is discussed below.

Luan $\left(31^{\circ} 20^{\prime} 21.3^{\prime \prime} \mathrm{N}, 77^{\circ} 26^{\prime} 31.6^{\prime \prime} \mathrm{E}\right.$; elevation $\left.888 \mathrm{~m}\right)$ : Located $\sim 40 \mathrm{~km}$ upstream of Shakra village, the section is exposed by a tributary stream emanating from a $\sim 42 \mathrm{~km}^{2}$ catchment area having a slope of 0.19 .

Stratigraphy: The lowermost horizon contains $\sim 0.3 \mathrm{~m}$ thick, gritty sand (unit-I). This is overlain by $\sim 0.4 \mathrm{~m}$ thick, platy and angular lithoclast (unitII) and is overlain by $\sim 0.3 \mathrm{~m}$ thick gritty course sand (unit-III). Overlying this is $\sim 0.75 \mathrm{~m}$ thick, angular to sub-angular pebble layer (unit-IV) which is succeeded by $\sim 0.75 \mathrm{~m}$ thick, platy angular gravels (unit-V). Finally, sequence terminates with the deposition of $\sim 4 \mathrm{~m}$ thick angular gravels (unit-VI).

Considering small catchment areas, both debris flows and alluvial fan sediments owe their genesis to the presence of fractured and fissile catchment lithology which is a pre-requisite for alluvial fan sedimentation (Blair and McPherson 1994; Leeder 2009). The study area is traversed with regional and local faults (MCT, Shalighat thrust, and Suketi thrust) (figure 1), as a result the local lithology is sheared. Alluvial fans which are intermediate deposits between normal stream flow and debris flow deposits (Bull 1972, 1964) resulting from hyperconcentrated flood/flow in region are spasmodically introduced into a fluvial system. However, the sedimentary facies of alluvial fan show alternate upward fining packages where, each package represents a complete cycle of high discharge coupled with its weaning phase. Usually, hiatuses in alluvial fan sedimentation are represented by pedogenized and/or weathered horizons (Tablot 1979). Absence of incipient paedogenesis in alluvial fan sediments suggest that there were insignificant breaks during alluvial fan sedimentation (Kochel 1990). This in turn may also be interpreted as deposition under short-lived episodic high precipitation events and probably associated with transient climates (McDonald et al. 2003).

\subsection{Paleo-flood deposits}

Paleo-flood deposits are used to infer the past flood magnitude, frequency, and discharge along with periods of extreme climates (Ely et al. 1992; Thorndycraft et al. 2005). Such deposits in Himalaya (from upper Ganga valley), have been used to reconstruct the past flood history spanning the last 1000 years. The studies implicated breaching of the landslide dam during intensified ISM (Srivastava et al. 2008; Wasson et al. 2008, 2013).

Paleo-flood deposits are observed either (i) proximal to the trunk river or (ii) are deposited in the tributary valleys (sheltered locations). Deposits 
proximal to the trunk river channel are frequently modified by subsequent floods and thus, seldom preserve a longer flood history. Comparatively, in sheltered locations the sequences are continuous and provide a longer history of high magnitude past floods (Kochel and Baker 1982; Baker 1987, 2008). Paleo-flood sequences are built by vertical accretion successive large floods, where the stratigraphically higher flood units indicate higher associated discharges (Baker 1987). Presence of pedogenised/weathered horizons within the flood couplet indicates hiatuses between the succeeding flood events (Thomas et al. 2007).

Paleo-flood deposits are observed at multiple locations overlying older aggradation surface and younger aggradation surface between Rampur and Tattapani (figure 5). At Bithal $\left(31^{\circ} 21^{\prime} 05.8^{\prime \prime} \mathrm{N} ; 77^{\circ}\right.$ $\left.28^{\prime} 55.7^{\prime \prime} \mathrm{E}\right)$, Gharyana $\left(31^{\circ} 14^{\prime} 39.6^{\prime \prime} \mathrm{N} ; 77^{\circ} 05^{\prime} 59.2^{\prime \prime} \mathrm{E}\right)$, Randhol $\left(31^{\circ} 14^{\prime} 59.4^{\prime \prime} \mathrm{N} ; 77^{\circ} 06^{\prime} 21.7^{\prime \prime} \mathrm{E}\right)$ and Sunni1 $\left(31^{\circ} 14^{\prime} 43.6^{\prime \prime} \mathrm{N} ; 77^{\circ} 07^{\prime} 04.8^{\prime \prime} \mathrm{E}\right)$, the deposits are associated with older aggradation surface. At Duttnagar $\left(31^{\circ} 23^{\prime} 41.8^{\prime \prime} \mathrm{N} ; 77^{\circ} 35^{\prime} 03.3^{\prime \prime} \mathrm{E}\right)$, Tattapani $\left(31^{\circ} 14^{\prime} 41.8^{\prime \prime}\right.$ $\mathrm{N} ; 77^{\circ} 05^{\prime} 41.2^{\prime \prime} \mathrm{E}$ and $\left.31^{\circ} 14^{\prime} 48.8^{\prime \prime} \mathrm{N} ; 77^{\circ} 05^{\prime} 28.7^{\prime \prime} \mathrm{E}\right)$, and Sunni-2 $\left(31^{\circ} 14^{\prime} 44.9^{\prime \prime} \mathrm{N} ; 77^{\circ} 07^{\prime} 01.0^{\prime \prime} \mathrm{E}\right)$ flood deposits are located on younger aggradation surface.

Duttnagar: Located $\sim 10 \mathrm{~km}$ downstream from Rampur (left bank of Satluj river), the deposits occur $\sim 25 \mathrm{~m}$ above the river bed. The deposits overlie younger aggradation surface and laterally extend towards the valley flank. In the absence of grain size data, interpretation is based on visual observations in the field which allow identification of six flood units. The lowermost horizon is $\sim 100 \mathrm{~cm}$ thick which contain $80 \mathrm{~cm}$ thick, planar laminated coarse sand and is overlain by $20 \mathrm{~cm}$ thick, sandy-clay (unit-I). This is overlain by $30 \mathrm{~cm}$ thick, planar cross-stratified coarse to medium sand containing dispersed calcrete and is capped by $10 \mathrm{~cm}$ thick, silty-sand (unit-II). The overlying $200 \mathrm{~cm}$ thick unit-III is dominantly coarse, planar laminated sand and is succeeded by $100 \mathrm{~cm}$ thick, gritty channel sand (unit-IV). A $600 \mathrm{~cm}$ thick, coarse to medium planar laminated sand which at places is massive and contains both nodular and bedded calcretes, is capped by a moderately rich sandy-silt dominated humus layer (unit-V). The topmost horizon is $300 \mathrm{~cm}$ thick, planar to massive, coarse gritty sand which eventually grades into silty-sand (unit-VI). The horizon is overlain by matrix dominated alluvial fan facies (figure 5).

Bithal: The flood deposits occur as a distal flood plain facies along the left flank of Satluj River at an elevation of $\sim 60 \mathrm{~m}$ above the river bed and laterally merges with older aggradation surface. Based on sediment texture, seven sedimentary units are identified. The micaceous sand dominated succession overlies $\sim 1 \mathrm{~m}$ thick, planar to cross-stratified sand. Unit-I is divided into the lower $25 \mathrm{~cm}$ thick horizon, dominated by fine sand with occasional calcretes and upper $15 \mathrm{~cm}$ thick horizon containing dark brown silty-clay. Succeeding $35 \mathrm{~cm}$ thick unit-II is divided into lower $25 \mathrm{~cm}$ thick horizon containing massive fine sand followed by upper $10 \mathrm{~cm}$ thick horizon dominated by dark brown silt and clay. This is succeeded by $40 \mathrm{~cm}$ thick, buff coloured unit-III dominated by fine to very fine sand. Succeeding this is $115 \mathrm{~cm}$ thick, chocolate brown coloured unit-IV, divided into lower $80 \mathrm{~cm}$ thick, coarse to medium sand and upper $35 \mathrm{~cm}$ thick, silty-clay. This unit is incised by a local channel which is represented by assorted fluvial gravel admixed with the local angular lithoclast. The overlying unit- $\mathrm{V}$ is $15 \mathrm{~cm}$ thick, buff coloured, crudely laminated fine sand with dispersed nodular calcrete and is capped by $3 \mathrm{~cm}$ thick, buff coloured clay. This is succeeded by $400 \mathrm{~cm}$ thick, parallel laminated (rhythmic) coarse to medium sand capped by $10 \mathrm{~cm}$ thick dark sandy-silt (unit-VI). Overlying this is a $100 \mathrm{~cm}$ thick, crudely laminated coarse to medium sand capped by anthropogenically modified silty-clay (unit-VII) (figure 5).

Sunni-1: The flood deposits are preserved along the course of a northerly draining seasonal stream around $\sim 35 \mathrm{~m}$ above the Satluj river bed. The mica rich sediment succession overlies cross and planar stratified angular pebbles. Based on the sediment texture and degree of weathering/pedogenesis, seven flood units are identified. The lowermost unit-I is $215 \mathrm{~cm}$ thick, which is differentiated into a lower $150 \mathrm{~cm}$ thick, coarse to medium grey sand with dispersed rhizolith, a middle $55 \mathrm{~cm}$ thick, fine sand and an upper $10 \mathrm{~cm}$ thick, fine sand with dispersed humus. The overlying $50 \mathrm{~cm}$ thick, unit-II is moderately weathered. In the field though no obvious fining upward gradation is observed, however, presence of bedded calcretes indicates that the sediments were exposed (during hiatus) before the onset of the subsequent flood events. This is succeeded by $70 \mathrm{~cm}$ thick unit-III, in which the lower $60 \mathrm{~cm}$ thick horizon is dominated by coarse to medium sand. The upper $10 \mathrm{~cm}$ thick horizon is dominated by fine sand. Overlying this is $35 \mathrm{~cm}$ thick unit-IV, which has a lower $30 \mathrm{~cm}$ thick fine sand overlain by $5 \mathrm{~cm}$ thick, weathered, humus rich layer. The overlying $310 \mathrm{~cm}$ thick unit- $\mathrm{V}$ is differentiated into lower $280 \mathrm{~cm}$ thick fine sand capped by a $30 \mathrm{~cm}$ thick, humus rich silty-sand. Overlying this is a $30 \mathrm{~cm}$ thick unit-VI, of which the lower 20 $\mathrm{cm}$ thick is dominated by fine sand, overlain by a 10 $\mathrm{cm}$ thick, humus rich silty-sand. The unit-VII is a $140 \mathrm{~cm}$ thick, containing dispersed calcareous nodules in the lower $50 \mathrm{~cm}$ and is succeeded by $150 \mathrm{~cm}$ thick dark to light grey massive coarse to medium sand (unit-VIII). The uppermost unit-IX is $150 \mathrm{~cm}$ thick massive medium to fine sand (figure 6). 


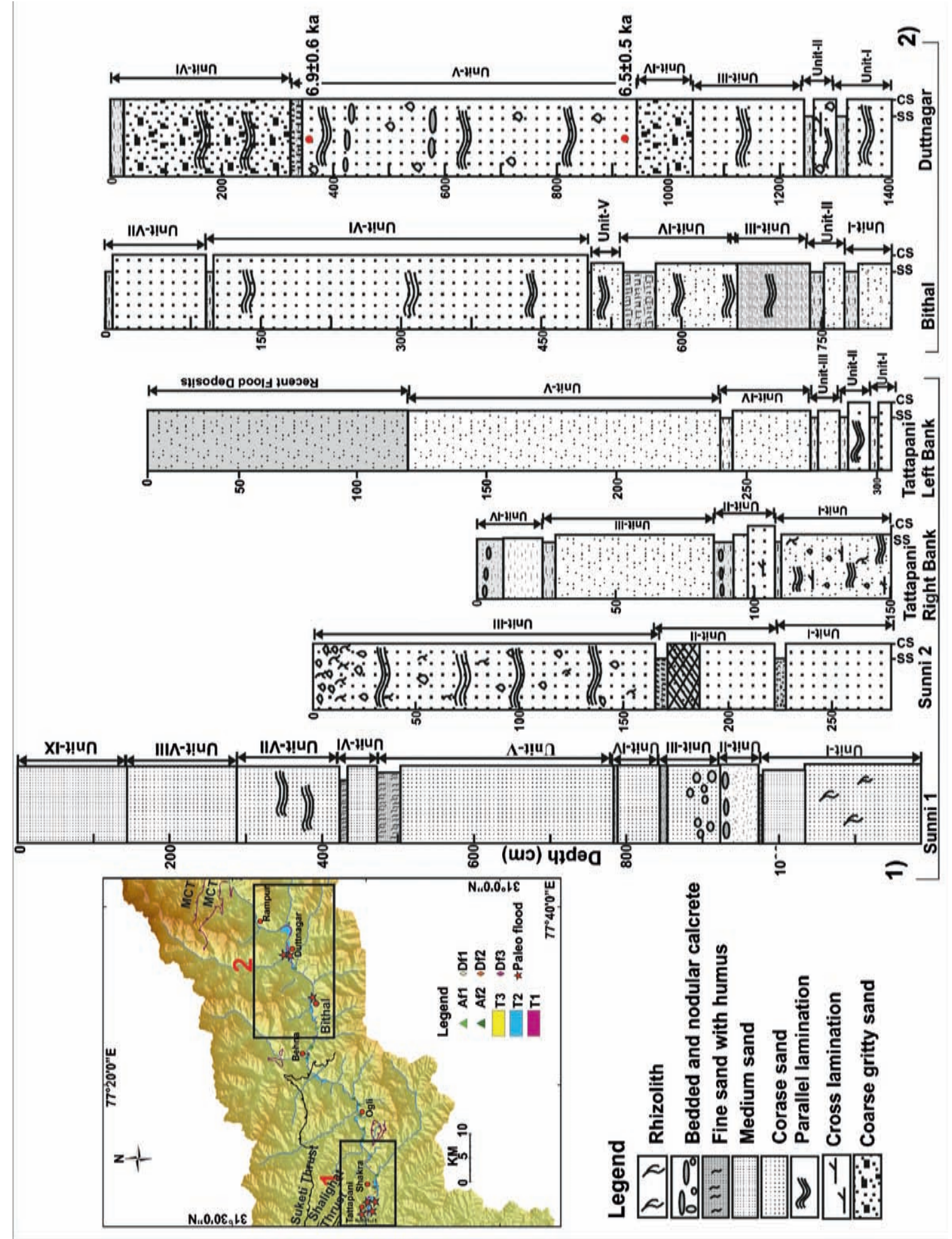

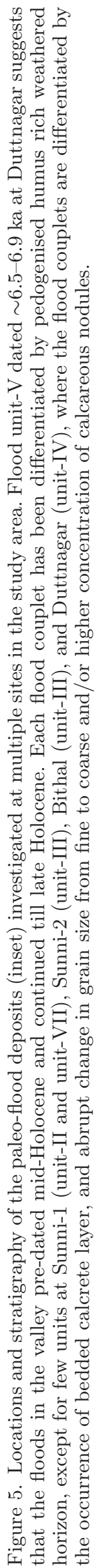




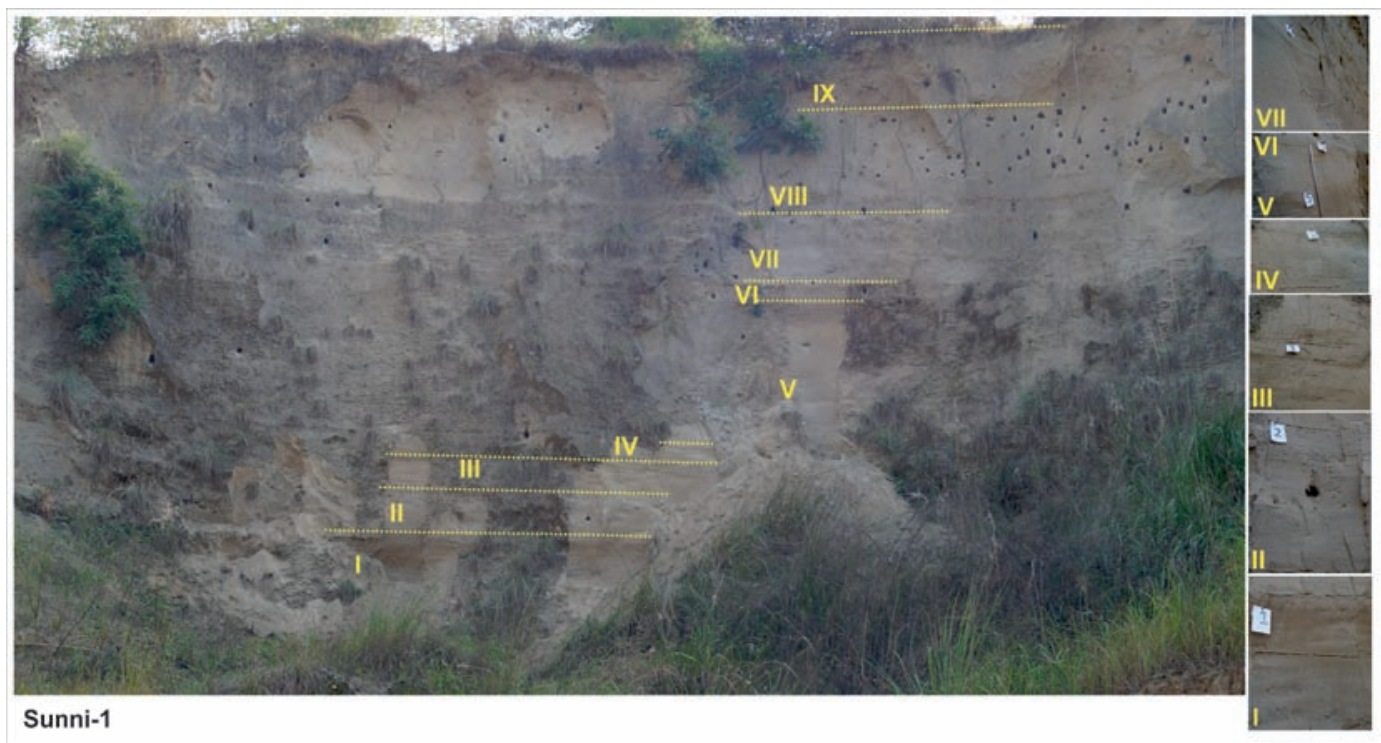

Figure 6. Field photograph and the close-ups of Sunni-1 paleo-flood deposits located at Sunni.

Sunni-2: The paleo-flood deposits of Sunni-2 are located $\sim 100 \mathrm{~m}$ downstream of Sunni-1, where three micaceous rich fining upward sequences are differentiated. The lowermost unit-I is $55 \mathrm{~cm}$ thick, which is differentiated into $50 \mathrm{~cm}$ thick lower micaceous fine sand, overlain by $5 \mathrm{~cm}$ thick desiccated sandy-clay. The overlying $60 \mathrm{~cm}$ thick unit-II has lower $40 \mathrm{~cm}$ thick fine sand, a middle $15 \mathrm{~cm}$ thick, rubified weathered horizon and an upper $5 \mathrm{~cm}$ thick humus rich horizon. The uppermost unit-III is $160 \mathrm{~cm}$ thick, where lower $140 \mathrm{~cm}$ is dominated by faintly laminated fine sand containing dispersed calcrete nodules and rhizo-concretions (figure 5).

Interpretation: Field observations demonstrate that the deposition occurred under relatively low energy environment and each flood unit show a gradation in the grain size with uppermost flood couplet invariably dominated by relatively finer size fractions. Presence of either weathered humus rich horizons or bedded calcrete layers in the flood sequences indicate reasonable time hiatuses between the succeeding flood events. Combining the laterally distributed flood sequences in the study area, it can be suggested that Satluj River experienced at least nine major floods of increasing magnitude in the past.

\subsection{Epigenetic gorges}

Epigenetic gorges and associated fossil valleys are common features in a tectonically active orogen. The term 'epigenetic' refers to the secondary nature of bedrock gorges, formed due to lateral shifting of a channel by accelerated sedimentation either from landslide debris, alluvial fans or widespread fluvial aggradation (Pant 1975;
Kothyari and Juyal 2013). Formation of epigenetic gorges and associated fossil valleys relies upon the bedrock geometry and original valley configuration. Bedrock geometry affects the location and lateral mobility of incising channel, whereas original valley shape determines rates of bedrock incision (Ouimet et al. 2008). The morphology and sediment characteristics of epigenetic gorges can be used to ascertain the processes (climate) responsible for accelerated sedimentation, and structural (tectonics) and lithological control (if any) in their evolution (Kothyari and Juyal 2013).

Two generations of fossil valleys and associated epigenetic gorges are observed in the study area near Ogli village $\left(31^{\circ} 15^{\prime} 45.6^{\prime \prime} \mathrm{N}, 77^{\circ} 16^{\prime} 40.5^{\prime \prime} \mathrm{E}\right.$; elevation $751 \mathrm{~m}$ ) (figure $2 \mathrm{~b}$ ). Fossil valleys also exist near Tattapani $\left(31^{\circ} 15^{\prime} 15.5^{\prime \prime} \mathrm{N}, 77^{\circ} 04^{\prime} 37.2^{\prime \prime} \mathrm{E}\right)$, Luhri $\left(31^{\circ} 20^{\prime} 51.8^{\prime \prime} \mathrm{N}, 77^{\circ} 27^{\prime} 19.2^{\prime \prime} \mathrm{E}\right)$, and Behna $\left(31^{\circ} 20^{\prime}\right.$ $\left.38.6^{\prime \prime} \mathrm{N}, 77^{\circ} 21^{\prime} 10.7^{\prime \prime} \mathrm{E}\right)$. The older fossil valley contains moderate to well sorted gravels punctuated by multiple sand bodies and texturally correspond to the major valley-fill sequences observed near Shakra (older aggradation surface). The younger fossil valley lying proximal to the present day river bed is stratigraphically equivalent to younger aggradation surface. Plugged with assorted boulders and sand with an upstream slope and separated from the present day channel by a prominent rock spur (figure 2b), it suggests that the older channel was abandoned as a result of increased sediment flux. Consequently, active channel laterally migrated in the upper reaches into the pre-existing subsidiary channel. Therefore, in accordance with the earlier observations (Kothyari and Juyal 2013; Chaudhary et al. 2015), the evolution of the fossil valleys and associated gorges can be 
ascribed to the events of climatically induced high sediment flux.

Ages based on the weighed mean of the equivalent dose (Juyal et al. 2006) indicate that the older aggradation phase (T2) is dated to $13.0 \pm 1 \mathrm{ka}$ (Duttnagar) and $10.8 \pm 1 \mathrm{ka}$ (Shakra). The sediment corresponding to the younger aggradation phase (T1) at Duttnagar and Tattapani are dated between $5.2 \pm 0.4$ and $0.4+0.0 \mathrm{ka}$, respectively. The flood plain sediments (palaeo-flood deposits) at Duttnagar are dated to $6.9 \pm 0.6$ and $6.5 \pm 0.5 \mathrm{ka}$. Table 1 gives the radioactivity values, equivalent dose and the ages obtained.

\section{Discussion}

\subsection{Climate variability}

Fluvial dynamics is widely recognized as the primary control on style and pace of landscape evolution in areas outside the realm of glaciers. As observed in actively deforming mountain belts, rivers flowing within few meters of bedrock (Tinkler and Wohl 1998) are continuously incising with insignificant sediment storage (similar to present day Satluj River). However, considering the discontinuous records of valley-fills, alluvial fans and debris flow deposits, it can be suggested that incision was punctuated by climatically driven pulses of aggradation (Pratt-Sitaula et al. 2004). Based on field stratigraphy and limited optical ages, two distinct phases of aggradations are observed. The older phase of aggradation (T2), constitute a major landform in the study area. This event is dated between $\sim 13$ and $\sim 11 \mathrm{ka}$ and suggests deposition during the post-glacial revival of ISM (Sirocko et al. 1993; Schulz et al. 1998) and accords well with the textural data discussed earlier. For example, the clast-supported angular to subrounded gravel is interpreted as deposition under flashy hydrological discharge with sudden mobilisation of sediment from the upper catchment. Such abrupt sediment flux is usually associated with a shift from dry to wetter conditions (transient climate) (Moscariello et al. 2002, 2009 and references therein). Similar observation was also made by Suresh et al. (2007) from the lower Satluj valley. Following this, the sediments are represented by moderate to well rounded, imbricated gravels separated by impersistent lensoidal sand horizons (point bars) suggesting that sediment supply outpaced the fluvial transport capacity. This can either happen by the decrease in river gradient or an increase in sediment flux (Pratt-Sitaula et al. 2004). We tend to suggest that high sediment flux associated with the strengthening of post-glacial ISM was responsible for the older aggradation

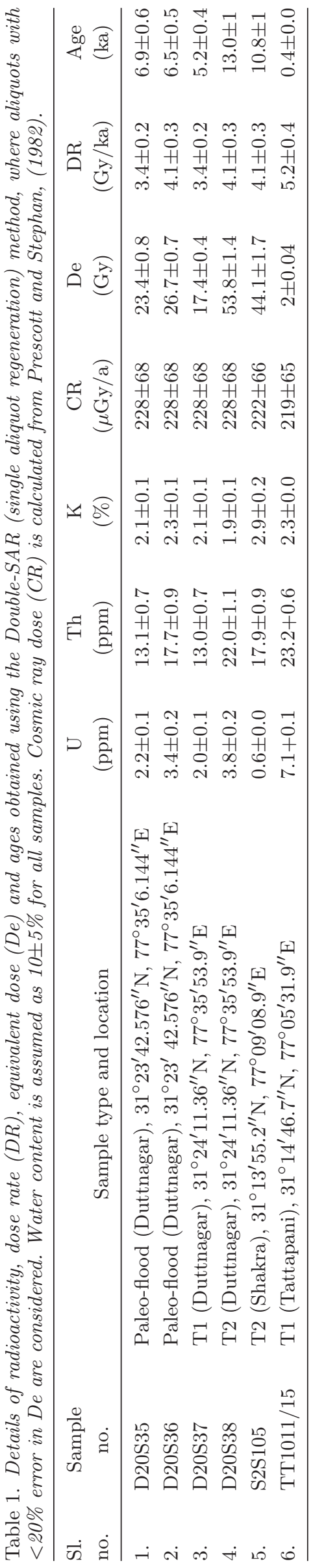


phase in the middle Satluj valley. Corroborative evidences of post-glacial strengthened monsoons are well represented in various records from central Himalaya. For example, Sinha et al. (2005) observed consistent depleted oxygen isotope values in speleothem record from the western Himalaya during 15-13 ka. Similarly, Beukema et al. (2011), Juyal et al. (2009), and Srivastava et al. (2013), using major geochemical and isotopic proxies in relict lake sediments from central Himalaya suggest a gradual improvement of the ISM after LGM.

In the absence of uppermost ages for the older valley-fill, it is difficult to infer the longevity of the aggradation event. However, considering that the terraces are incised to various depths, studies suggest incision was facilitated during periods of reduced sediment flux in weak ISM (Pratt et al. 2002; Bookhagen et al. 2006; Juyal et al. 2010; Chaudhary et al. 2015). We speculate that the second aggradation phase continued beyond $\sim 11$ ka probably till early mid-Holocene ( $\sim 6 \mathrm{ka})$. This seems logical considering that the palaeoflood deposits which are laterally comparable with the upper part of the older aggradation phase (discussed below) are dated to $\sim 6.5$ ka. Thereafter the ISM began to decline in Satluj valley as suggested by Bookhagen et al. (2006).

The middle Satluj valley experienced at least nine high magnitude floods. Presence of pedogenised/ weathered horizons associated with each flood couplet suggests variable hiatuses in the flood recurrence frequencies. Presence of mica in the flood couplets suggests that floods were triggered by the landslide dam outburst in the Higher Himalaya Crystalline zone. This accords well with the observations made by Bookhagen et al. (2005) that exceptionally large mass movements occurred during middle Holocene in the upper catchment of Satluj valley. Similar evidences accrued from the monsoon dominated Alaknanda valley where landslide dam bursts are implicated for multiple high magnitude floods during last 1 ka (Wasson et al. 2008, 2013, 2008). Optical ages of 6.9 and 6.5 ka on the flood unit-V at Duttnagar (figure 5) suggest that Satluj valley responded to unusual weather events during the early to mid-Holocene. Most importantly successive increase in flood magnitude probably indicates increase in severity of extreme weather events in the study area. However, definitive answers would await more detailed analysis of the flood sequences in the middle Satluj valley which is in progress.

The youngest aggradation phase is represented dominantly by a strath surface and suggests reduced sediment supply from the catchment area. At places local debris flows have been fluvially modified to form younger fluvial surface, while at places, older aggradation surface has been scoured to deposit the sediments. Importantly, there is an appreciable bedrock incision $(2-4 \mathrm{~m})$ associated with the strath terrace which perhaps indicates relatively higher bedrock uplift after younger aggradation which is dated between $\sim 5$ and $\sim 0.4$ ka. The facies assemblages dominated by channel and point bar thus suggest frequent lateral avulsion (within the confines) of Satluj River during fluctuating hydrological conditions (Singh et al. 2007). The youngest debris flows and the alluvial fans overlying younger aggradation phase $(<0.4 \mathrm{ka})$ can be interpreted as local slope instability caused during short-lived intensified rainfall events. The fossil valleys and associated epigenetic gorges further support till mid-Holocene, the middle Satluj valley witnessed episodic high sediment fluxes which exceeded the transport capacity of Satluj River.

The sporadic and extreme events like debris flows, floods, epigenetic gorges and alluvial fans are the sedimentological expressions and responses of the terrain to the variability in the ISM (Wasson et al. 2008, 2013). The sediment mobilization occur in surges both during enhanced and transient climatic conditions (Dorn 1994; McDonald et al. 2003; Bookhagen et al. 2005; Juyal et al. 2010). An appreciable contribution of debris flows, alluvial fans and landslides is observed in the older fluvial aggradation phase particularly around the Main Central Thrust (MCT). The landslides in upper Satluj valley are ascribed to the abnormal monsoon events (Bookhagen et al. 2005). However, our study indicates that the debris flows and alluvial fans are also triggered by the same mechanism. Compared to this, in the middle Satluj valley (south of MCT), these events are associated with transitional climatic conditions.

\subsection{Tectonics}

In a tectonically active orogen like Himalaya, crustal deformation is a continuous process. On a regional scale, crustal shortening/uplift can be assumed to be constant for different segments in Himalaya (Vance et al. 2003). Study in the foothills of Nepal Himalaya suggests that during the last 10 ka crustal shortening was fairly constant (Lavé and Avouac 2001). At a local scale, however, abnormal uplift in the proximity of major and minor structures can modify the river profile (Tyagi et al. 2009). The fluvial sediment associated with the older aggradation phase required large accommodation space. Was the accommodation space created immediately prior to the aggradation under low sediment water ratio along with tectonics (Pratt-Sitaula et al. 2004)? Or, alternatively, did the deposition occur in the preexisting valley topography? Morphology of the 


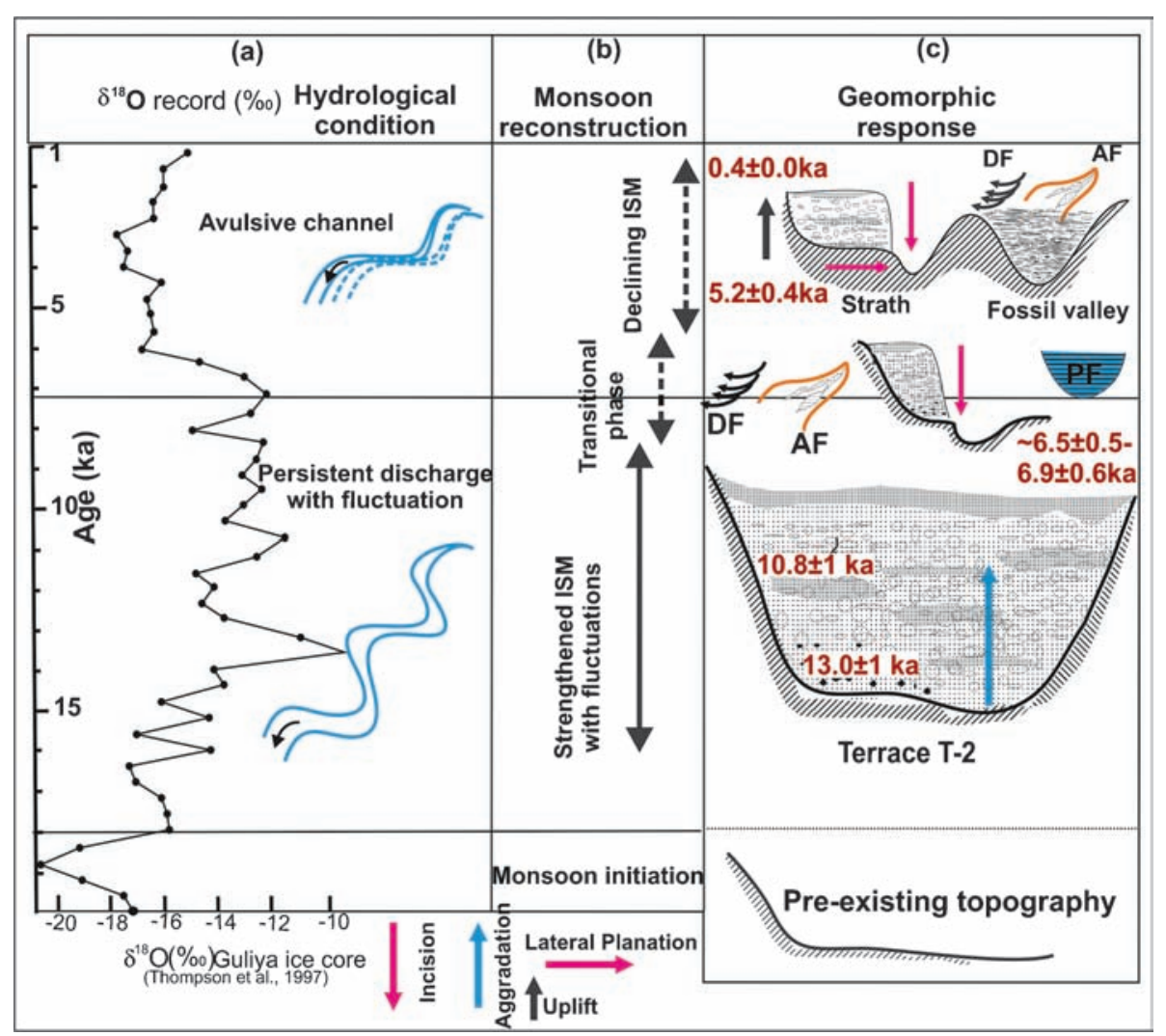

Figure 7. Summary diagram plotted against the (a) Guliya ice core $\left(\delta^{18} \mathrm{O}\right)$ : a surrogate for the Indian summer monsoon variability (Thompson et al. 1997). The enriched oxygen isotopic values suggest strengthened ISM and vice-versa. Also shown is the temporal changes in the hydrological condition (b) Inferred Indian Summer Monsoon and (c) The geomorphic response. Accommodation space for older aggradation ( $13-6.5 \mathrm{ka})$ was available in pre-existing topography. During this period shallow landslides and oldest debris flows were also generated. The major flood events, second major debris flow (DF2) and the first major alluvial fan (AF2) sedimentation occurred under fluctuating ISM after early Holocene and continued till mid-Holocene. Relatively enhanced bedrock uplift after mid-Holocene during overall declining ISM was accompanied by youngest generation of debris flows (DF1) and alluvial fans (AF1) caused due to sporadic rainfall events under transition climate. The phase continued until around the late Holocene $(\sim 0.4 \mathrm{ka})$.

older aggradation phase at multiple locations, viz., Chebdi $\left(31^{\circ} 14^{\prime} 28.7^{\prime \prime} \mathrm{N}, 77^{\circ} 12^{\prime} 16.5^{\prime \prime} \mathrm{E}\right)$; Jaishi $\left(31^{\circ} 15^{\prime} 08.3^{\prime \prime} \mathrm{N} ; 77^{\circ} 14^{\prime} 57.9^{\prime \prime} \mathrm{E}\right) ;$ Kot $\left(31^{\circ} 20^{\prime} 54.8^{\prime \prime} \mathrm{N}\right.$; $\left.77^{\circ} 24^{\prime} 58.2^{\prime \prime} \mathrm{E}\right) ;$ Nirath $\left(31^{\circ} 23^{\prime} 15.47^{\prime \prime} \mathrm{N}, 77^{\circ} 34^{\prime} 03.9^{\prime \prime}\right.$ E); and Nainj $\left(31^{\circ} 20^{\prime} 14.5^{\prime \prime} \mathrm{N}, 77^{\circ} 20^{\prime} 33.3^{\prime \prime} \mathrm{E}\right)$ show that the deposits are confined by the vertically incised valley flanks representing relict channel topography. Thus, in the central part of the relict aggraded channel there is no bedrock incision, instead the river flowed through the older aggraded sediments. The lateral correlation of the sediments corresponding to the older aggradation phase indicates existence of a broad sinuous course. In view of this, we speculate that the pre-existing valley topography that existed much before the older aggradation phase and probably created by multiple events of incision/uplift, provided the accommodation space for the older aggradation phase. Following the aggradation, the incision seems to occur during the weakened ISM, thus, can be attributed to the reduced sediment supply. An expression of relative displacement (differential uplift?) is observed near Shakra village where the older aggradation (T2) is juxtaposed by a laterally persistent strath terrace and associated gorge in downstream (figure 3). Such channel morphology is ascribed to when a river crosses a fault(Whittaker et al. 2007). This could be a localized expression of tectonic instability after the older aggradation phase in the study area. Nevertheless, the morphology of the younger aggradation phase (T1) which is dominated by the strath surface can be interpreted as evidence of relatively enhanced bedrock uplift after $\sim 0.4$ ka (figure 7).

\section{Conclusions}

This study based on detailed field mapping, stratigraphy, sedimentology and limited optical chronology allows us to draw the following broad inferences.

The monsoon dominated middle Satluj valley responded to a combination of ISM variability and 
tectonics during the post-Last Glacial Maximum (LGM). The older aggradation phase is ascribed to the post-LGM strengthening of ISM.

Although preliminarily in nature, our observations suggest that the older aggradation was accommodated in the pre-existing valley topography that was carved by multiple events of incision and uplift.

The valley experienced major floods caused due to breaching of landslide dams in upper catchment (Higher Himalayan Crystalline). As suggested by Bookhagen et al. (2005), we ascribe the formation of landslide dams to the abnormal monsoon events during the early to middle Holocene period. Successive higher magnitude flood events are ascribed to increased severity of extreme rainfall events and associated landslide dam outbursts.

To the south of MCT, incision of valley-fill sediments (T2) and the reactivation of tributary valleys and hillslope processes causing debris flow and alluvial fan sedimentation occurred during the weakened ISM (post-LGM and $\sim 6.5 \mathrm{ka}$ ) which is in contrast to the upper Satluj valley where these processes were activated during abnormal monsoon years (Bookhagen et al. 2005). Younger aggradation surface (dated between $\sim 5$ and $\sim 0.4 \mathrm{ka}$ ) development is ascribed to the weak and fluctuating ISM, with considerable contribution from locally mobilised sediments. It appears that the terrain experienced relatively enhanced bedrock uplift (incision) after $\sim 0.4 \mathrm{ka}$.

\section{Acknowledgements}

The study forms part of $\mathrm{PhD}$ thesis of Shubhra Sharma. We are grateful to the Director, Wadia Institute of Himalayan Geology, Dehradun for encouragement and support. We also acknowledge Dr Pradeep Srivastava for fruitful discussions and help with OSL data. NASA and GLIMS (Global Land Ice Measurements from Space) is recognised for providing ASTER L1B data product. The assistance provided by the local people in the field is duly acknowledged. They are greatly thankful to the anonymous reviewers for constructive comments which helped in improving the manuscript.

\section{References}

Anderson S W, Anderson S P and Anderson R S 2015 Exhumation by debris flows in the 2013 Colorado Front Range storm; Geology 43(5) 391-394.

Aitken M J 1998 An Introduction to Optical Dating; Academic Press, London, 276p.

Attal M and Lavé J 2006 Changes of bedload characteristics along the Marsyandi River (central Nepal): Implications for understanding hillslope sediment supply, sediment load evolution along fluvial networks, and denudation in active orogenic belts; Geol. Soc. Am. Bull. 398 143-171.

Baker V R 1987 Paleoflood hydrology and extraordinary flood events; J. Hydrol. 96(1) 79-99.

Baker V R 2002 High-energy megafloods: Planetary settings and sedimentary dynamics (eds) Martini I P and Baker V R; Spec. Publ. Int. Assoc. Sedimentol. 32 3-15.

Baker V R 2008 Paleoflood hydrology: Origin, progress, prospects; Geomorphology 101(1) 1-13.

Banerjee D, Singhvi A K, Pande K, Gogte V D and Chandra B P 1999 Towards a direct dating of fault gouges using luminescence dating techniques - methodological aspects; Curr. Sci. 77 256-269.

Barnard P L, Owen L A, Sharma M C and Finkel R C 2001 Natural and human-induced landsliding in the Garhwal Himalaya of northern India; Geomorphology 40 21-35.

Barnard P L, Owen L A and Finkel R C 2004 Style and timing of glacial and paraglacial sedimentation in a monsoon-influenced high Himalayan environment, the upper Bhagirathi valley, Garhwal Himalaya; Sedim. Geol. 165 199-221.

Benn D I and Owen L A 1998 The role of the Indian summer monsoon and the mid-latitude westerlies in Himalayan glaciation review and speculative discussion; J. Geol. Soc. London 155 353-363.

Beukema S P, Krishnamurthy R V, Juyal N, Basavaiah N and Singhvi A K 2011 Monsoon variability and chemical weathering during the late Pleistocene in the Goriganga basin, higher central Himalaya, India; Quat. Res. 75(3) 597-604.

Blair T C and McPherson J G 1994 Alluvial fan processes and forms; In: Geomorphology of desert environments, Springer, Netherlands, pp. 354-402.

Blair T C 1999 Cause of dominance by sheet flood $v$ s. debris-flow processes on two adjoining alluvial fans, Death Valley, California; Sedimentology 46(6) 1015-1028.

Blöthe J H and Korup O 2013 Millennial lag times in the Himalayan sediment routing system; Earth Planet. Sci. Lett. 382 38-46.

Bogaart P W and Van Balen R T 2000 Numerical modeling of the response of alluvial rivers to Quaternary climate change; Global Planet Change 27 147-163.

Bookhagen B, Thiede R C and Strecker M R 2005 Late Quaternary intensified monsoon phases control landscape evolution in the northwest Himalaya; Geology 33(2) $149-152$.

Bookhagen B, Fleitmann D, Nishiizumi K, Strecker M R and Thiede R C 2006 Holocene monsoonal dynamics and fluvial terrace formation in the northwest Himalaya, India; Geology 34(7) 601-604.

Bridgland D and Westaway R 2008 Climatically controlled river terrace staircases: A worldwide Quaternary phenomenon; Geomorphology 98 285-315.

Bull W B 1964 History and causes of channel trenching in western Fresno County, California; Am. J. Sci. 262 249-258.

Bull W B 1972 Recognition of alluvial fan deposits in the stratigraphic record; SEPM Spec. Publ. 16 63-83.

Bull W B 1991 Geomorphic Responses to Climatic Change; Oxford University Press, New York, 326p.

Bull W B 1997 Discontinuous ephemeral streams; Geomorphology 19(3) 227-276.

Chaudhary S, Shukla U K, Sundriyal Y P, Srivastava P and Jalal P 2015 Formation of paleovalleys in the central Himalaya during valley aggradation; Quat. Int. 371 254-267.

Clift P D, Giosan L, Blusztajn J, Campbell I H, Allen C, Tabrez A R, Rabbani M M, Alizai A and Lückge A 2012 
Holocene erosion of the Lesser Himalaya triggered by intensified summer monsoon; Geology 36 79-82.

Coe J A and Godt J W 2012 Review of approaches for assessing the impact of climate change on landslide hazards; In: Landslides and engineered slopes, protecting society through improved understanding (eds) Eberhardt E, Froese C, Turner A K and Leroueil S, Proceedings of the 11th International and 2nd North American Symposium on Landslides and Engineered Slopes, Banff, Canada 1 371-377.

Costa J E and Fleisher P J 1984 Developments and Applications of Geomorphology; Springer-Verlag, Berlin, 386p.

District Disaster Management Authority (DDMA), Kinnaur, http://hp.gov.in/ddma-kinnaur/page/History.aspx.

Dorn R 1994 The role of climatic change in alluvial fan development; In: Geomorphology of Desert Environments (eds) Abraham A D and Parsons A J, Springer, pp. 593-615.

Dutta S, Suresh N and Kumar R 2012 Climatically controlled Late Quaternary terrace staircase development in the fold-and-thrust belt of the SubHimalaya; Palaeogeogr. Palaeoclimatol. Palaeoecol. 356 16-26.

Eaton B C and Lapointe M F 2001 Effects of large floods on sediment transport and reach morphology in the cobble-bed Sainte Marguerite River; Geomorphology 40 291-309.

Ely L L, Enzel Y, Baker V R and Cayan D R 1992 A 5000year record of extreme floods and climate change in the southwestern United States; Science 256 14-34.

Luhri Project Report 2010 Environment Impact Assessment of Luhri H.E. Project, Himachal Pradesh; Centre for Interdisciplinary Studies of Mountain and Hill environment, University of Delhi, 462p.

Finnegan N J, Roe G, Montgomery D R and Hallet B 2005 Controls on the channel width of rivers: Implications for modeling fluvial incision of bedrock; Geology 33(3) 229-232.

Fisher R V 1971 Features of coarse-grained, highconcentration fluids and their deposits; J. Sedim. Res. 41(4) 916-927.

Goodbred S L 2003 Response of the Ganges dispersal system to climate change: A source-to-sink view since the last interstade; Sedim. Geol. 162 83-104.

Grant G E and Swanson F J 1995 Morphology and processes of valley floors in mountain streams, western Cascades, Oregon; Geophysical Monograph - Am. Geophys. Union 89 83-101.

Griffiths P G and Webb R H 2004 Frequency and initiation of debris flows in Grand Canyon, Arizona; J. Geophys. Res. 109 1-15.

GSI 1976 Memoirs of the Geological Surv. India 106 (I, II), Government of India.

Gupta V and Shah M P 2008 Impact of the trans-Himalayan landslide lake outburst flood (LLOF) in the Satluj catchment, Himachal Pradesh, India; Natural Hazards 45(3) 379-390.

Hancock G S and Anderson R S 2002 Numerical modeling of fluvial strath-terrace formation in response to oscillating climate; Geol. Soc. Am. Bull. 114(9) 11311142 .

Howard A D, Dietrich W E and Seidl M A 1994 Modeling fluvial erosion on regional to continental scale; $J$. Geophys. Res. Solid Earth (1978-2012) 99(B7) 13,97113,986 .

Iverson R M, Reid M E and LaHusen R G 1997 Debris-flow mobilization from landslide; Ann. Rev. Earth Planet. Sci. 25(1) 85-138.

Jahns R H 1949 Desert floods; Engineering and Science Newsletter California Institute of Technology 12 10-14.
Juyal N, Pant R K, Basavaiah N, Yadava M G, Saini N K and Singhvi A K 2004 Climate and seismicity in the higher Central Himalaya during 20-10 ka evidence from the Garbayang basin, Uttaranchal, India; Palaeogeogr. Palaeoclimatol. Palaeoecol. 213 315-330.

Juyal N, Chamyal L S, Bhandari S, Bhushan R and Singhvi A K 2006 Continental record of the southwest monsoon during the last 130 ka evidence from the southern margin of the Thar Desert, India; Quat. Sci. Rev. 25(19) 2632-2650.

Juyal N, Pant R K, Basavaiah N, Bhushan R, Jain M, Saini N K, Yadava M K and Singhvi A K 2009 Reconstruction of Last Glacial to early Holocene monsoon variability from relict lake sediments of the Higher Central Himalaya, Uttarakhand, India; J. Asian Earth Sci. 34 $437-449$.

Juyal N, Sundriyal Y P, Rana N, Chaudhary S and Singhvi A K 2010 Late Quaternary fluvial aggradation and incision in the monsoon-dominated Alaknanda valley, Central Himalaya, Uttarakhand, India; J. Quat. Sci. 25(8) 1293-1304.

Kale V S 2003 Geomorphic effects of monsoon floods on Indian rivers; Natural Hazards 28 65-84.

Kale V S 2007 Geomorphic effectiveness of extraordinary floods on three large rivers of the Indian peninsula; Geomorphology 85 306-316.

Kochel R C and Baker V R 1982 Paleoflood hydrology; Science 215 353-361.

Kochel R C 1990. Humid fans of the Appalachian Mountains; In: Alluvial Fans: A Field Approach; Wiley, New York, pp. 109-129.

Korup O, Densmore A L and Schlunegger F 2010 The role of landslides in mountain range evolution; Geomorphology $12077-90$.

Kothyari G C and Juyal N 2013 Implications of fossil valleys and associated epigenetic gorges in parts of central Himalaya; Curr. Sci. 105(3) 383-388.

Lancaster S T and Grant G E 2006 Debris dams and the relief of headwater streams; Geomorphology 82 84-97.

Lavé J and Avouac J P 2001 Fluvial incision and tectonic uplift across the Himalayas of central Nepal; J. Geophys. Res. 106(B11) 26,561-26,591.

Lavigne F and Suwa H 2004 Contrasts between debris flows, hyper concentrated flows and stream flows at a channel of Mount Semeru, East Java, Indonesia; Geomorphology 61(1) $41-58$.

Leeder M R 2009 Sedimentology and sedimentary basins from turbulence to tectonics; John Wiley and Sons, Chicago, 581p.

Major J J 1997 Depositional processes in large-scale debrisflow experiments; J. Geol. 105(3) 345-366.

Malamuda B D, Turcotte D L, Guzzettic F and Reichenbach P 2004 Landslides, earthquakes and erosion; Earth Planet. Sci. Lett. 229 45-59.

McDonald E V, McFadden L D and Wells S G 2003 Regional response of alluvial fans to the Pleistocene-Holocene climatic transition; In: Paleoenvironments and Paleohydrology of the Mojave and Southern Great Basin Deserts (eds) Enzel Y, Wells S G and Lancaster N; Geol. Soc. Am. 368 189-205.

McCoy S W 2015 Infrequent, large-magnitude debris flows are important agents of landscape change; Geology 43(5) 463-464.

Miall A D 1996 The geology of fluvial deposits; Springer Verlag, Berlin, 582p.

Moscariello A, Marchi L, Maraga F and Mortara G 2002 Alluvial fans in the Italian Alps sedimentary facies and processes (eds) Martini I P and Baker V R; Spec. Publ. Int. Assoc. Sedimentol. 32 141-166. 
Moscariello A, Marchi L, Maraga F and Mortara G 2009 Alluvial fans in the Italian Alps sedimentary facies and processes; In: Flood and Megaflood Processes and Deposits; Recent and Ancient Examples (Spec. Publ. 32 of the IAS) 17141.

Murray A S and Wintle A G 2000 Luminescence dating of quartz using an improved single aliquot regenerative-dose protocol; Radiat. Meas. 32 57-73.

Ouimet W B, Whipple K X, Crosby B T, Johnson J P and Schildgen T F 2008 Epigenetic gorges in fluvial landscapes; Earth Surf. Process. Landf. 33(13) 19932009.

Pant G 1975 Observation on the fossil valleys and epigeneric gorges of the Bhagirathi and Alaknanda rivers; Him. Geol. 5 193-206.

Pearce A J and Watson A 1983 Medium-term effects of two landsliding episodes on channel storage of sediment; Earth Surf. Process. Landf. 8 29-39.

Pierson T C 1980 Erosion and deposition by debris flows at Mt Thomas, north Canterbury, New Zealand; Earth Surf. Process. 5(3) 227-247.

Pratt B, Burbank D W, Heimsath A and Ojha T 2002 Impulsive alluviation during early Holocene strengthened monsoons, central Nepal Himalaya; Geology 30(10) 911-914.

Pratt-Sitaula B, Burbank D W, Heimsath A and Ojha T 2004 Landscape disequilibrium on 1000-10,000 year scales Marsyagndi River, Nepal, central Himalaya; Geomorphology 58 223-241.

Prescott J R and Stephan L G 1982 Contribution of cosmic radiation to environmental dose; PACT 6 17-25.

Ray Y and Srivastava P 2010 Widespread aggradation in the mountainous catchment of the Alaknanda-Ganga river system timescales and implications to Hinterlandforeland relationships; Quat. Sci. Rev. 29 2238-2260.

Reading H G 2009 Sedimentary environments: Processes, facies and stratigraphy; John Wiley and Sons, 704p.

Roberts H M and Wintle A G 2001 Equivalent dose determinations for polymineralic fine-grains using the SAR protocol application to a Holocene sequence of the Chinese Loess Plateau; Quat. Sci. Rev. 20(5) 859-863.

Scheidegger A E 1998 Tectonic pre-design of mass movements, with examples from the Chinese Himalaya; Geomorphology 26 37-46.

Schmidt K M and Montgomery D R 1995 Limits to relief; Science 270(5236) 617-620.

Schulz H, von Rad U and Erlenkeuser H 1998 Correlation between Arabian Sea and Greenland climate oscillations of the past 110,000 years; Nature 393(6680) 54-57.

Sharma S, Joachimski M, Sharma M, Tobschall H J, Singh I B, Sharma C, Chauhan M S and Morgenroth G 2004 Late glacial and Holocene environmental changes in Ganga Plain, northern India; Quat. Sci. Rev. 23 145159.

Singh M, Singh I B and Müller G 2007 Sediment characteristics and transportation dynamics of the Ganga River; Geomorphology 86(1) 144-175.

Sinha A, Cannariato K G, Stott L D, Li C H, You C F, Cheng H, Edwards R L and Singh I B 2005 Variability of southwest Indian summer monsoon precipitation during the Bølling-Ållerød; Geology 33 813-816.

Sirocko F, Sarnthein M, Erlenkeuser H, Lange H, Arnold M and Duplessy J C 1993 Century-scale events in monsoonal climate over the past 24,000 years; Nature $\mathbf{3 6 4}$ $322-324$.

Smith G A 1986 Coarse-grained non-marine volcaniclastic sediment terminology and depositional process; Geol. Soc. Am. Bull. 97 1-10.

Srikantia S V and Bhargava O N 1988 Geology of Himachal Pradesh; Geol. Soc. India, 406p.
Srivastava P, Tripathi J K, Islam R and Jaiswal M K 2008 Fashion and phases of late Pleistocene aggradation and incision in the Alaknanda river valley, western Himalaya, India; Quat. Res. 70 68-80.

Srivastava P, Kumar A, Mishra A, Meena N K, Tripathi J K, Sundriyal Y P and Gupta A K 2013 Early Holocene monsoonal fluctuations in the Garhwal higher Himalaya as inferred from multi-proxy data from the Malari paleolake; Quat. Res. 80(3) 447-458.

Suresh N, Bagati T N, Kumar R and Thakur V C 2007 Evolution of Quaternary alluvial fans and terraces in the intramontane Pinjaur Dun, Sub-Himalaya, NW India: Interaction between tectonics and climate change; Sedimentology 54 809-833.

Starkel L 2003 Climatically controlled terraces in uplifting mountain areas; Quat. Sci. Rev. 22 2189-2198.

Talbot M R and Williams M A J 1979 Cyclic alluvial fan sedimentation on the flanks of fixed dunes, Janjari, central Niger; Catena 6(1) 43-62.

Thakur V C and Rawat B S 1992 Geological map of the Western Himalaya, Survey of India.

Thiede R C, Bookhagen B, Arrowsmith J R, Sobela E R and Streckera M R 2004 Climatic control on rapid exhumation along the southern Himalayan Front; Earth Planet. Sci. Lett. 222 791-806.

Thomas E R, Wolff E W, Mulvaney R, Steffensen J P, Johnsen S J, Arrowsmith C and Popp T 2007 The 8.2 ka event from Greenland ice cores; Quat. Sci. Rev. 26(1) $70-81$.

Thompson L O, Yao T, Davis M E, Henderson K A, MosleyThompson E, Lin P N and Bolzan J F 1997 Tropical climate instability: The last glacial cycle from a QinghaiTibetan ice core; Science 276(5320) 1821-1825.

Thorndycraft V R, Benito G, Rico M, Sopeña A, SánchezMoya Y and Casas A 2005 A long-term flood discharge record derived from slackwater flood deposits of the Llobregat River, NE Spain; J. Hydrol. 313(1) 16-31.

Tinkler K J and Wohl E E 1998 Rivers over rock: Fluvial processes in bedrock channels, Washington, D.C.; Am. Geophys. Union 323.

Tyagi A K, Chaudhary S, Rana N, Sati S P and Juyal N 2009 Identifying areas of differential uplift using steepness index in the Alaknanda basin, Garhwal Himalaya, Uttarakhand; Curr. Sci. 97 1473-1477.

Vandenberghe J 1995 Timescales, climate and river development; Quat. Sci. Rev. 14 631-638.

Vance D, Bickle M, Ivy-Ochs S and Kubik P W 2003 Erosion and exhumation in the Himalaya from cosmogenic isotope inventories of river sediments; Earth Planet. Sci. Lett. 206(3) 273-288.

Viseras C, Calvache M L, Soria J M and Fernández J 2003 Differential features of alluvial fans controlled by tectonic or eustatic accommodation space. Examples from the Betic Cordillera, Spain; Geomorphology 50 181202.

Waitt R B 2002 Great Holocene floods along Jökulsá á Fjöllum, north Iceland (eds) Martini I P and Baker V R, Spec. Publ. Int. Assoc. Sedimentol. 32 37-51.

Wasson R J, Juyal N, Jaiswal M, McCulloch M, Sarin M M, Jain V, Srivastava P and Singhvi A K 2008 The mountain-lowland debate: Deforestation and sediment transport in the upper Ganga catchment; J. Environ. Manag. 88 53-61.

Wasson R J, Sundriyal Y P, Chaudhary S, Jaiswal M K, Morthekai P, Sati S P and Juyal N 2013 A 1000-year history of large floods in the Upper Ganga catchment, central Himalaya, India; Quat. Sci. Rev. 77 156-166.

Whipple K X 2004 Bedrock rivers and the geomorphology of active orogens; Ann. Rev. Earth Planet. Sci. 32 151-85. 
Whittaker A C, Cowie P A, Attal M, Tucker G E and Roberts G P 2007 Bedrock channel adjustment to tectonic forcing: Implications for predicting river incision rates; Geology 35(2) 103-106.

Wobus C, Heimsath A, Whipple K and Hodges K 2005 Active out-of-sequence thrust faulting in the central Nepalese Himalaya; Nature 434 1008-1011.

Wulf H, Bookhagen B and Scherler D 2012 Climatic and geologic controls on suspended sediment flux in the Sutlej
River Valley, western Himalaya; Hydrol. Earth Syst. Sci. $162193-2217$.

Zhang J F and Zhou L P 2007 Optimization of the double SAR procedure for polymineral fine grains; Radiat. Meas. 42(9) 1475-1482.

Zygmunt E 2009 Alluvial fans as an effect of long-term manlandscape interactions and moist climatic conditions: A case study from the Glubczyce Plateau, SW Poland; Geomorphology 108 58-70. 